\title{
Investigation of the Strategies for Targeting of the Afterglow Nanoparticles to Tumor Cells
}

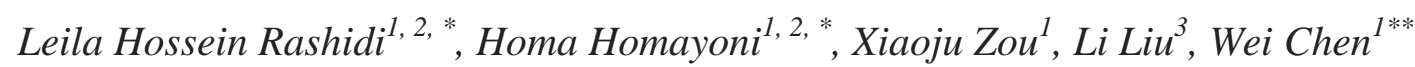

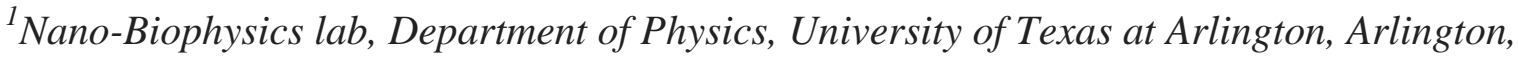
Texas, USA

${ }^{2}$ Joint Biomedical Engineering Program, University of Texas at Arlington, Arlington, TX

${ }^{3}$ University of Texas Southwestern Medical Center, Dallas, TX

*These two authors contributed equally to this work

**Corresponding author: Wei Chen: weichen@uta.edu

\begin{abstract}
Afterglow nanoparticles have been widely investigated as new agents for cancer imaging and as a light source for photodynamic activation for cancer treatment. For both applications, the targeting of the afterglow nanoparticles to tumor cells is an important and challenging issue. Here we report the strategies for targeting $\mathrm{Sr}_{3} \mathrm{MgSi}_{2} \mathrm{O}_{8}: \mathrm{Eu}^{2+}, \mathrm{Dy}^{3+}$ afterglow nanoparticles to tumor cells by conjugating with variety of targeting molecules such as folic acid, RGD peptide, and R-11 peptide. For folic acid targeting, experimental observations were conducted on PC-3 cells (folate receptor negative), MCF-7 (folate receptor positive), and KB cells (folate receptor positive) to compare the cellular uptake and confirm targeted delivery. For the cyclic RGDfK peptide, experiments were carried out on the integrin $\alpha_{v} \beta_{3}$ positive MDA-MB-231 breast cancer cell line and the integrin $\alpha_{v} \beta_{3}$ negative MCF-7 breast cancer cell lines in order to compare the cellular uptakes. As for R11-SH peptide, cellular uptake of the afterglow nanoparticles was observed on LNCaP and PC3 prostate cancer cell lines. All the observations showed that the cellular uptakes of the nanoparticles were enhanced by conjugation to variety of targeting molecules which are specific for breast and prostate cancer cells.
\end{abstract}

\section{Keywords}

Afterglow nanoparticles, Targeting, Biomolecules, Cancer treatment 


\section{1- Background:}

Afterglow materials which are also called long-lasting phosphors or persistent luminescence materials which lifetimes prolong from a minutes to hours [1, 2]. Human have known about the phenomenon of persistent luminescence for over 1000 years. Ancient Chinese artists had mixed colors and special kinds of pearl shells to create afterglow properties on their paintings. In 1602, a shoemaker and alchemist Vincenzo Casciarolo discovered the Bologna stone, which had afterglow properties. Later on in 1640, Fortunius Licetus explained this phenomenon scientifically. It was believed that available barium sulfide in the rock had created the afterglow. Indeed, it was explained that existing natural impurities of stone had prolonged its afterglow. Very little research has been guided on afterglow phenomenon until the end of the 20th century. Zinc sulfide $(\mathrm{ZnS})$ doped with copper (and then co-doped with cobalt) was the most common afterglow for many years [2-4]. Its application was in commercial products such as glow-in-the-dark toys, luminous paints, and watch dials. However, its short decay time and weak brightness had limited its practical approaches. Traces of radioactive elements such as promethium or tritium were employed to solve the mentioned issues [2, 5]. But the proposed solution could not decrease the high concentration of luminescent material used in commercial glow-in-the-dark objects to show acceptable afterglow. In August 1996, at the same time, two different groups of Matsuzawa and Takasaki [2, 6, 7] independently synthesized a long lasting afterglow that was 10 times brighter than $\mathrm{ZnS}: \mathrm{Cu}$,Co which was previously used widely. They introduced the rare earth element dysprosium $\left(\mathrm{Dy}^{3+}\right)$ as a co-dopant into the green-emitting phosphor $\mathrm{SrAl}_{2} \mathrm{O}_{4}: \mathrm{Eu}^{2+}[2,7]$ leading to an afterglow which was able to emit hours after removing the source of energy. This progress encouraged researchers for different and better persistent afterglow materials. Alkaline earth aluminates were the most common materials for the mentioned studies for a long time. $\mathrm{Sr}_{2} \mathrm{MgSi}_{2} \mathrm{O}_{7}: \mathrm{Eu}^{2+}, \mathrm{Dy}^{3+}$ afterglow particles were introduced by $\mathrm{Lin}$ and related research teams in $2001 . \mathrm{Sr}_{2} \mathrm{MgSi}_{2} \mathrm{O}_{7}: \mathrm{Eu}^{2+}, \mathrm{Dy}^{3+}$ particles demonstrated very bright and a long decay time [2,8]. Later on, other doped (di) silicates were showing long afterglow and were synthesized. Research and studies have been focused on the synthesis of the new afterglow compounds. Although it has been 18 years since the first report of long lasting $\mathrm{SrAl}_{2} \mathrm{O}_{4}: \mathrm{Eu}^{2+}, \mathrm{Dy}^{3+}$ afterglow particle, the number of the known afterglow compounds with long lasting decay time and good brightness is still limited $[2,3]$. 
Persistent luminescence materials can be found in daily life such as emergency lighting, safe traffic, luminous paints, textiles ceramics, and wall painting [2, 9]. Recently, persistent luminescence or afterglow materials have been studied as light source for photodynamic activation on cancer treatment and animal imaging. When the nanoparticle-photosensitizer conjugates are targeted to the tumor, the light from afterglow nanoparticles will activate the photosensitizers, so that no external light is required for photodynamic therapy. More importantly, it can be used to treat deep tumor such as breast cancer because the light source is attached to the photosensitizers, so the efficiency of cancer diagnosis and treatment is enhanced. Upon exposure to ionizing radiation such as X-rays, nanoparticles emit luminescence which activates the photosensitizers; thus, singlet oxygen is produced to kill cancer cells along with ionizing radiation. Therefore, the combination of conventional radiation therapy and PDT enables the use of lower doses of radiation. PDT could result in selective and irreversible destruction of diseased tissues such as cancerous tissue, without damaging healthy cells. Another important advantage of PDT as compared to conventional methods is outpatient therapeutic property of PDT. Moreover, PDT can induce immunity, even against less immunogenic tumors, resulting in long-term tumor control. However, there is no total agreement about the dominant factor for stimulating an immune response. Some results demonstrated that apoptotic tumor cells are the leader in inducing an immune response, but others discussed the effective role of necrotic tumor cells in activating an immune response. Although afterglow nanoparticles have introduced many advantages so far, choosing a photosensitizer in with less accumulation and higher wavelength (deep tissue) is encouraged for effective diagnosis and treatment. [1, 2, 10-13].

For both cancer imaging and treatment applications, the targeting of the afterglow nanoparticles to tumor cells is an important and challenging issue. Here we report the strategies for targeting $\mathrm{Sr}_{3} \mathrm{MgSi}_{2} \mathrm{O}_{8}: \mathrm{Eu}^{2+}, \mathrm{Dy}^{3+}$ afterglow nanoparticles to tumor cells by conjugating with variety of targeting molecules such as folic acid, RGD peptide and R-11 peptide. Two general strategies have been demonstrated for the targeting of nanoparticulate systems to folate receptorpositive tumor cells: by coupling to a monoclonal antibody against the receptor and by coupling to a high affinity ligand, folic acid. In the first strategy, antibodies against the folate receptor, have been applied for tumor imaging and immunotherapy. The second strategy has been successfully used in vitro for the receptor-specific delivery of protein toxins, anti-T-cell receptor antibodies, interleukin-2, chemotherapy agents, $\gamma$-emitting radiopharmaceuticals, magnetic 
resonance imaging contrast agents, liposomal drug carriers, and gene transfer vectors. It was shown that low molecular weight radiopharmaceuticals based on folate conjugates results in much more desired pharmacokinetic properties than radiolabeled antibodies and greater tumor selectivity in folate receptor-positive animal tumor models. The small size, high affinity, convenient availability, simple conjugation chemistry, and presumed lack of immunogenicity of folic acid make it an ideal ligand for targeted delivery to tumors. [14] Folic acid could bind to folate receptors over-expressed on variety of human cancers including: breast, ovaries, endometrium, renal cell carcinoma, lungs, kidneys, colon, brain metastases, colorectal, and neuroendocrine carcinoma. The only concern about folic acid is that, folate receptors (FRs) are expressed both on tumor tissue as well as normal epithelia in the choroids plexus, placenta, lung, intestine, and kidney. However, FRs are expressed on luminal surface of epithelial cells in the case of breast and prostate tissues, which is not exposed to blood circulation. [15-17] RGD Peptide (c(RGDfK)), which is a small size oligopeptide-based ligand, with lower immunogenicity, higher stability, and ease of manufacture in comparison with antibodies and is clinically used for lung and pancreatic cancer. It can specifically bind to integrin $\alpha_{v} \beta_{3}$ which possess high expression on breast cancer cells and angiogenetic endothelial cells as compared to normal cells. It is more specific to breast cancer as compared to folic acid, but its receptor is still both expressed on cancer cells and normal epithelial cells. However phage display screen method could isolate these peptides to achieve high specificity and affinity. Also cyclic RGD peptide such as $\mathrm{c}(\mathrm{RGDfK})$ which was used in this study offer high receptor binding affinity and specificity for cancer cells.[15-22]. R11 peptide is an oligoarginine cell permeable peptide with high prostate cancer specificity. It is the best efficient delivery system among the peptides tested in several prostate cancer cell lines. Unlike the first two biomolecules in which the mechanism of uptake was receptor mediated endocytosis, in this case the mechanism of uptake is via Macropinocytosis through Laminin Receptor Protein (37LRP). [23-25]

In order to reach the goal of this research, fluorescent imaging was performed for folic acid, RGD peptide and R11 peptide conjugated afterglow nanoparticles to study the cellular uptake for different cell lines with different degree of receptors on their surface. For folic acid targeting, experimental observations were conducted on PC-3 cells (folate receptor negative), MCF-7 (folate receptor positive), and $\mathrm{KB}$ cells (folate receptor positive) to compare the cellular uptake and confirm targeted delivery. For the cyclic RGDfK peptide, experiments were carried out on 
the integrin $\alpha_{\mathrm{v}} \beta_{3}$ positive MDA-MB-231 breast cancer cell line and the integrin $\alpha_{\mathrm{v}} \beta_{3}$ negative MCF-7 breast cancer cell lines in order to compare the cellular uptakes. As for R11-SH peptide, cellular uptake of the afterglow nanoparticles was observed on LNCaP and PC3 prostate cancer cell lines.

\section{Materials and Methods:}

\subsection{Materials:}

Folic acid (FA), 1-Ethyl-3-(3-dimethylaminopropyl)carbodiimide (EDC), Nhydroxysuccinimide (NHS), (3-Aminopropyl) triethoxysilane (APTES), 2-(Nmorpholino)ethanesulfonic acid (MES buffer), Sulfosuccinimidyl 4-(N-maleimidomethyl) cyclohexane-1-carboxylate sodium salt (Sulfo-SMCC), fetal bovine serum (FBS; 10\%), Penicillin/Streptomycin, paraformaldehyde (PFA), Sodium hydroxide $(\mathrm{NaOH})$, sterilized phosphate buffered saline (PBS), and Trypsin were all purchased form Sigma-Aldrich. MTT reagent was purchased from Trevigen Inc. KB cells (ATCC number CCL-17), MCF-7 cells (ATCC number HTB-22), PC-3 cells (ATCC number CRL-1435), LNCaP cells (ATCC number CRL-1740), Eagle's minimum essential medium (EMEM) and F-12 K medium were all purchased from ATCC company. VECTASHIELD ${ }^{\circledR}$ Mounting Medium with PI (Ex: 535 nm, Em: $615 \mathrm{~nm}$ ) was purchased from Vector Company. Cyclo (- RGDfK) was purchased from AnaSpec company. R11 peptide, MCF-7, MDA-MB-231 cell lines and Dulbecco's Modified Eagle Medium (DMEM) were provided form University of Texas Southwestern Medical Center at Dallas. Ethylenediaminetetraacetic acid (EDTA) was provided by Drug Delivery lab, University of Texas at Arlington. Toluene (mallinckrodt Chemicals Company) and Dimethyl sulfoxide (DMSO) (VWR International) were used as solvents.

\subsection{Synthesis and surface modification of $\mathrm{Sr}_{3} \mathrm{MgSi}_{2} \mathrm{O}_{8}: \mathrm{Eu}^{2+}, \mathrm{Dy}^{3+}$ particles}

$\mathrm{Sr}_{3} \mathrm{MgSi}_{2} \mathrm{O}_{8}: \mathrm{Eu}^{2+}, \mathrm{Dy}^{3+}$ was synthesized by modified sol-gel method. All starting materials including $\mathrm{SrCO}_{3}, 4 \mathrm{MgCO}_{3} \bullet \mathrm{Mg}(\mathrm{OH})_{2} \bullet 5 \mathrm{H}_{2} \mathrm{O}, \mathrm{Eu}_{2} \mathrm{O}_{3}, \mathrm{Dy}_{2} \mathrm{O}_{3}$ in stoichiometric ratio were suspended in equal volume of tetraethyl orthosilicate (TEOS) and ethanol. The deionized water was added drop wise into the solution in a 3 necked- flask which was stirring vigorously under sonication. Molar ratio ( $\mathrm{R}$ ) of $\mathrm{H}_{2} \mathrm{O} / \mathrm{Si}$ was chosen equal 2, to have the optimum hydrolysis reaction. The $\mathrm{pH}$ was adjusted by adding appropriate amount of hydrochloric acid ( $\mathrm{HCl})$ into the solution as a catalyst. The solution was heated and refluxed up to $80{ }^{\circ} \mathrm{C}$ till sol-gel was formed. 
Reactions were conducted under different $\mathrm{pH}$ values and temperatures in order to observe the dependence of the luminescence on synthetic conditions. The samples from Sol-Gel were dried at $150{ }^{0} \mathrm{C}$ for 3 hours in a weak reductive atmosphere prepared by charcoal powder. The dried powder was grinded and transformed to a furnace for calcination at $1050{ }^{\circ} \mathrm{C}$ covered by charcoal for 2 hours and the final products were obtained and characterized for crystal structure and luminescence properties. To decrease the particle size, the above $\mathrm{Sr}_{3} \mathrm{MgSi}_{2} \mathrm{O}_{8}$ : $\mathrm{Eu}^{2+}, \mathrm{Dy}^{3+}$ particles were grounded in a $7.5 \mathrm{mM} \mathrm{NaOH}$ solution for $120 \mathrm{~min}$; then were treated and stirred in the same solution overnight to create water dispersible particles with $-\mathrm{OH}$ groups on their surfaces. The particles were then coated with (3-Aminopropyl) triethoxysilane (APTES) to create functional groups of $\mathrm{NH}_{2}$ as discussed in details in previous publications [26-32] and illustrates in Figure 1.

\subsection{Conjugation of Biomolecules to Afterglow Nanoparticles:}

\subsubsection{Conjugation of Folic acid to Afterglow Nanoparticles:}

The final product from above as shown in Figure 1 was conjugated to folic acid using the wellknown EDC/NHS chemistry as discussed in previous protocols [16, 18, 32-37]. Briefly, FA (5 $\left.\mathrm{mg}, 1.13 \times 10^{-5} \mathrm{~mol}\right)$ was dissolved in $1.5 \mathrm{ml}$ DMSO and activated by EDC $\left(13.5 \mathrm{mg}, 7 \times 10^{-5} \mathrm{~mol}\right)$ under constant stirring, at room temperature, in dark for 20 minutes. Then, NHS $\left(8 \mathrm{mg}, 7 \times 10^{-}\right.$ ${ }^{5} \mathrm{~mol}$ ) was added and the reaction was continued for 1 hour. The activated FA solution was added dropwise to disperse AG NPs in $1 \mathrm{ml}$ DI water $\left(10 \mathrm{mg}, 2.12 \times 10^{-5} \mathrm{~mol}\right)$, and the reaction was kept overnight. Finally, the resulting nanoparticles were centrifuged and washed three times with DMSO, water and PBS to remove all the unreacted reagents. Figure 2 illustrates the procedure of FA conjugation to AG NPs at room temperature using the prepared APTES coated NPs.

\subsubsection{RGD peptide Conjugation to Afterglow Nanoparticles:}

\subsubsection{Conjugation of RGD peptide to Persistent Luminescent Nanoparticles (Method 1):}

APTES-capped AG NPs with $\mathrm{NH}_{2}$ functional groups on the surface were used to further conjugate with $\mathrm{COOH}$ group on the surface of RGD peptide by using EDC/NHS chemistry. To this end, RGD peptide $\left(0.5 \mathrm{mg}, 8.28 \times 10^{-4} \mathrm{mmol}\right)$ was dissolved in $1 \mathrm{ml}$ DMSO. Then EDC $\left(10 \mathrm{mg}, 6.44 \times 10^{-2} \mathrm{mmol}\right)$, was added under constant stirring at room temperature, in dark. After 5 minutes, NHS $\left(10 \mathrm{mg}, 8.69 \times 10^{-2} \mathrm{mmol}\right)$ was added. The resulting solution was added dropwise to 
a solution of AG NPs in $1 \mathrm{ml}$ DMSO (10 mg, $\left.2.12 \times 10^{-5} \mathrm{~mol}\right)$ at room temperature and kept overnight. Subsequently the suspension was centrifuged and washed three times with DMSO, DI water and PBS [29, 33]. Figure 3 illustrates the procedure of RGD peptide conjugation to AG NPs using DMSO as a solvent.

\subsubsection{Conjugation of RGD peptide to Persistent Luminescent Nanoparticles (Method 2):}

Since, the RGD peptide used in this study had both $\mathrm{NH}_{2}$ and $\mathrm{COOH}$ functional groups, another method could be used to conjugate the RGD peptide to plasma coated AG NPs with $\mathrm{COOH}$ groups on the surface. Firstly, Plasma coated AG NPs (10 mg, $\left.2.12 \times 10^{-5} \mathrm{~mol}\right)$ were dispersed in $10 \mathrm{ml} 0.05 \mathrm{M}$ MES buffer solution ( $\mathrm{pH}=6)$. Then EDC $\left(10 \mathrm{mg}, 6.44 \times 10^{-2} \mathrm{mmol}\right)$ was added under constant stirring at room temperature, in dark. After 15 minutes, NHS (10mg, $\left.8.69 \times 10^{-2} \mathrm{mmol}\right)$ was added followed by adding RGD peptide $\left(0.5 \mathrm{mg}, 8.28 \times 10^{-4} \mathrm{mmol}\right)$ and the reaction was kept overnight. Subsequently the suspension was centrifuged and washed three times DI water and PBS [38-40]. Figure 4 illustrates the procedure of RGD peptide conjugation to plasma coated AG NPs.

\subsubsection{R11 peptide Conjugation to Afterglow Nanoparticles:}

APTES-capped AG NPs with $\mathrm{NH}_{2}$ on the surface were used to further conjugate with $\mathrm{SH}$ group on R11 peptide. $5 \mathrm{mg}$ of the prepared nanoparticles was dispersed in $5 \mathrm{ml}$ buffer solution (PBS-2.5 mM EDTA). Then $100 \mu \mathrm{L}$ of Sulfo-SMCC in DMSO $(14 \mathrm{mM})$ was added and stirred for 1 hour. Furthermore, 1mg R11 peptide was added and the solution was kept under constant stirring, for 3 hours at room temperature. Finally, $100 \mu \mathrm{l}$ of $20 \mathrm{mM}$ Cysteine was added to stop the reaction. Subsequently, the prepared nanoparticles were centrifuged and washed 3 times with DMSO and DI water to get rid of unreacted compounds [23-25, 41, 42]. Figure 5 illustrates the procedure of R11 peptide conjugation to AG NPs by using Sulfo-SMCC as a cross-linker.

\subsection{Characterization Methods:}

\subsubsection{Florescence}

The luminescence emission spectra were measured using a Shimadzu RF-5301PC spectrophotometer, in order to study and compare the photoluminescence properties of biomolecule conjugated AG NPs with bare AG NPs. The concentration of the conjugated FA- 
NPs, AG NPs alone and FA alone was about $3 \mathrm{mg} \mathrm{ml}^{-1}, 2.325 \mathrm{mg} \mathrm{ml}^{-1}$ and $0.625 \mathrm{mg} \mathrm{ml}^{-1}$, respectively which were calculated based on conjugation efficiency results.

\subsubsection{UV-Vis Absorption}

The optical absorption spectra were recorded on a Shimadzu 2450 ultraviolet-visible (UV-Vis) spectrophotometer. This device was used to confirm the FA conjugation as well as calculating the conjugation efficiency [35]. The concentration of the conjugate and AG NPs alone was maintained at $125 \mu \mathrm{g} \mathrm{ml}^{-1}$ and FA alone was measured in five different concentrations starting at 62.5 and serially diluting to $46.874,31.25,23.437$ and $15.625 \mu \mathrm{g} \mathrm{ml}^{-1}$. The five concentrations of FA was used to plot a standard curve for the intensity of the sharp peak of FA at $292 \mathrm{~nm}$ and the linear equation resulted from the standard curve, could be used to calculate the concentration of FA in FA-NPs sample. Notably, absorption spectra could be effectively used to confirm the conjugation of biomolecules, but it requires precise purification and washing of the material to make sure that there are no free molecules that could confound the analysis. In this study, the conjugated samples were centrifuged and washed more than three times to make sure that there was no free FA inside the solutions $[43,44]$.

\subsubsection{Dynamic Light Scattering (Size and Zeta Potential):}

The size of nanoparticles before conjugation, after $\mathrm{NaOH}$ soaking and FA conjugation, after FA conjugation and filtration was studied using Dynamic Light Scattering (DLS) method (Zeta PALS, Zeta potential analyzer, Brookhaven Instruments). Samples were measured in DI water with concentrations of $0.5 \mathrm{mg} \mathrm{ml}^{-1}$.

Also the surface charge of the nanoparticles before conjugation, after $\mathrm{NaOH}$ soaking, after APTES coating and after conjugation to FA was studied by using DLS device, in order to study the surface charge and stability of the nanoparticles as well as to confirm FA conjugation to AG NPs [45].

\subsection{In Vitro Cell Viability}

The cytotoxicity of AG NPs and FA-NPs under in vitro conditions in prostate (PC-3) was examined in terms of the effect of those nanoparticles on cell proliferation by the MTT assay [37]. Untreated cells (PBS-negative control) as well as cells treated with 62.5, 125, 250, 500,

$\mu \mathrm{g} . \mathrm{ml}^{-1}$ concentrations of the prepared nanoparticles for $24 \mathrm{~h}$ were subjected to the MTT assay for cell viability determination. In this assay, only cells that are viable after $24 \mathrm{~h}$ exposure to the 
sample are capable of metabolizing a dye (3-(4,5-dimethylthiazol-2-yl)-2,5-diphenyltetrazolium bromide) efficiently and produce purple colored crystals which are dissolved in a detergent and analyzed by spectrophotometer.

\subsection{In Vitro Imaging}

For folic acid conjugated afterglow nanoparticles, human nasopharyngeal epidermal carcinoma cell line KB and Human epithelial breast cancer cell line MCF-7 were cultured in EMEM and human prostate carcinoma cell line PC-3 was cultured in F-12 K medium, supplemented with $10 \% \mathrm{FBS}$ and $1 \%$ penicillin-streptomycin solution at $37^{\circ} \mathrm{C}\left(5 \% \mathrm{CO}_{2}\right)$. For RGD peptide conjugated afterglow nanoparticles MCF-7 and MDA-MB-231 cells were cultured in EMEM and DMEM, respectively. Finally for R11 conjugated afterglow nanoparticles PC-3 and LNCaP cells were cultured in F-12 K and EMEM medium, respectively.

Furthermore, cells were seeded in a 6-well plate and then the cells were treated with 100 $\mu \mathrm{g} / \mathrm{ml}$ nanoparticles. Cells were fixed with freshly prepared $4 \%$ paraformaldehyde (PFA) for 5 min and then washed three times with PBS. The cell nuclei were then stained with PI for $10 \mathrm{~min}$ followed by washing three times with PBS. Fluorescence imaging was done using Olympus 1X71 inverted fluorescence microscope in order to study and compare the cellular uptake for three different cell lines $[37,46,47]$.

\section{Results and Discussions:}

\section{Folic acid Conjugation to Afterglow Nanoparticles:}

The luminescence excitation and emission spectra of FA-NPs conjugates, AG NPs alone and FA alone dispersed in DI water are depicted in Figure 6. FA alone excited at $388 \mathrm{~nm}$ has an emission at around $450 \mathrm{~nm}[36,48,49]$. As the photoluminescence intensity for folic acid could be affected by varying the $\mathrm{pH}[48,49]$, all the samples were kept in the same $\mathrm{pH}$ (DI water). In addition, AG NPs alone excited at $350 \mathrm{~nm}$ also have the emission at $450 \mathrm{~nm}$ which is much stronger than that of FA [26]. For the FA-NPs conjugates excited at 350 or $388 \mathrm{~nm}$, the emission is at $450 \mathrm{~nm}$ but their intensity is weaker than the emission of AG alone. This means that the conjugation with FA quenches the luminescence of the particles. This is similar to what reported in literature for the quenching of quantum dot luminescence by conjugation with FA $[34,35]$. 
As afterglow nanoparticles are being investigated for medical imaging and photodynamic activation for cancer treatment $[1,2,10,11,26]$, it is important that they maintain strong luminescence and afterglow after conjugation with targeting molecules. Figure 7 shows the fluorescence and afterglow of $\mathrm{Sr}_{3} \mathrm{MgSi}_{2} \mathrm{O}_{8}: \mathrm{Eu}^{2+}, \mathrm{Dy}^{3+}$ particles conjugated to folic acid using two different methods under UV lamp. The afterglow is disappeared for the conjugates using MES buffer ( $\mathrm{pH}=6$ ) solution to conjugate FA to AG NPs (Figure 7A), while in the method using DMSO, both the luminescence and the afterglow maintained strong after the conjugation (Figure 7B). This means that the DMSO is a good method to prepare the conjugates that are promising for biological applications either for imaging or photodynamic therapy.

Figure 8 shows the absorption spectra of AG NPs alone, FA-AG NPs and FA alone (closest absorption intensity to FA-AG NPs is shown in figure). AG NPs alone have no absorption in the range of 200-900 nm. However, FA alone has a narrow peak at about $290 \mathrm{~nm}$ and a broader peak at $345 \mathrm{~nm}$. The AG-FA conjugates show similar absorption spectrum to FA, while their absorption peaks shifted a little to longer wavelength. The absorption spectra prove further that the conjugation is successful. Finally, the conjugation efficiency calculated based on the equation of $\mathrm{y}=0.0121 \mathrm{x}+0.6164$ and $\mathrm{R}^{2}=0.9377$ was $28.053 \mu \mathrm{g}$ FA per $125 \mu \mathrm{g}$ AG-FA NPs.

The DLS measurement shows that the surface charge for AG NPs is $-24.85 \pm 0.94 \mathrm{mV}$, which is attributed to the $\mathrm{OH}$ groups on the surface of the nanoparticles introduced during synthesis [26, 37]. After wet grinding and $\mathrm{NaOH}$ soaking for 24 hours, the zeta potential is more negative $(-27.26 \pm 1.11 \mathrm{mV})$, this is because more $\mathrm{OH}$ groups were introduced by this process. However, After APTES coating, some negative surface groups were replaced by more positive $\mathrm{NH}_{2}$ groups, the zeta potential became $-12.64 \pm 0.83 \mathrm{mV}$. After the conjugation with folic acid, the zeta potential is increased to $-30.40 \pm 0.44 \mathrm{mV}$ which is due to ionization of the a-carboxylic group on FA $[33,48]$. All these results indicate that the surface modification and conjugation are successful.

In vitro cell viability was done to evaluate the dark toxicity and biocompatibility of the conjugated NPs. The results demonstrated that after 24 h, PC-3 cells showed excellent viability up to $\% 90$ after exposure of the cells to $500 \mu \mathrm{g} \cdot \mathrm{ml}^{-1}$ concentration of the FA conjugated-AG NPs 
(Figure 9). However, AG NPs alone showed a relative amount of toxicity at the highest concentration $\left(500 \mu \mathrm{g} \cdot \mathrm{ml}^{-1}\right)$, but maintained the viability for lower concentrations. [37] These results clearly demonstrated that FA conjugation provide a non-toxic coating on AG NPs nanoparticles. Thus, this nanoparticulate system provide no dark toxicity to cells, and may be studied in further studies for killing and treatment of cancer cells after activation by light. Furthermore, Cell viability of PNT1A (normal prostate epithelium) exposed to AG NPs was evaluated by MTT assay in another study [26]. In the mentioned study, the PNT1A cells were cultured in RPMI 1640 medium at 37C and 5\% CO2. The cells were plated into 96-well-plate inserts at 3000 cells per well and allowed to grow for 1 day. The cells were washed with PBS following by replacement of the medium, and then AG NPs were added at different concentrations up to $500 \mu \mathrm{g} \cdot \mathrm{ml}^{-1}$ and incubated for 24 hours. Their results demonstrated that almost $90 \%$ of PNT1A could survive after exposure to NPs with concentration up to $250 \mu \mathrm{g} \cdot \mathrm{ml}^{-1}$; since One-way ANOVA did not declare any significant differences between different concentrations (up to $500 \mu \mathrm{g} \cdot \mathrm{ml}^{-1}$ of NPs) in this study, they believed that AG NPs meet biocompatibility expectation.

The in vitro fluorescence imaging was performed on the PC-3 cell lines as FA receptor negative [50], MCF-7 cell lines as FA receptor positive (slightly) [51-55] and KB cells as FA receptor positive $[51,54]$ in order to observe and compare the cellular uptake and target recognition capability of FA conjugated AG NPs as shown in Figure 10. It is clearly shown in all the images that the cellular uptakes in the MCF-7 and KB cells (FA receptor positive) are much higher than that in the PC-3 cells (FA receptor negative). Also, it can be seen that the cellular uptake in KB cells is higher than in the MCF-7 cells because the expression of FA receptors in $\mathrm{KB}$ cells is higher than in MCF-7 cells. [51, 52] The high uptake in the KB cells and the MCF-7 cells are attributed to the high specific interaction between FA on the FA-NPs and folate receptor (FR) on the KB and MCF-7 cells resulting in more efficient internalization of the FA-NPs into the cells via FR-mediated endocytosis, which promoted the entry of the FA-NPs into FA receptor-overexpressed MCF-7 and KB cells.

\section{RGD Peptide Conjugation to Persistent Luminescence Nanoparticles:}

The cellular uptake of RGD-AG conjugates was observed on MCF-7 cell lines (integrin $\alpha_{v} \beta_{3}$ negative) and MDA-MB-231 cell lines (integrin $\alpha_{\mathrm{v}} \beta_{3}$ positive) [13, 19, 20, 56]. Figure 11 shows the results of the fluorescence imaging for method 1 which was carried out using APTES 
coated AG NPs in DMSO as a solvent [28, 33], and Figure 12 shows the results of method 2 which was performed using plasma coated NPs in MES buffer as a solvent[38-40]. As depicted in the figures, the cellular uptake in MDA-MB-231 cells (integrin $\alpha_{v} \beta_{3}$ positive) is significantly higher than in MCF-7 (integrin $\alpha_{\mathrm{v}} \beta_{3}$ negative). Because of the low level of integrin $\alpha_{\mathrm{v}} \beta_{3}$ on MCF-7 cell membrane, the uptake of cRGD conjugated AG NPs into MCF-7 cells is very low after the $24 \mathrm{~h}$ incubation in comparison with MDA-MB-23 which has high level of integrin $\alpha_{\mathrm{v}} \beta_{3}$ on their cell membranes $[13,20]$. By comparing the results for method 1 and 2 , method 2 shows relatively higher aggregation than method 1, especially in bright filed images. The conjugates from method 1 have better luminescence, afterglow and higher cell uptake than the conjugates from method 2. This means that method 1 is a good conjugation method for practical applications. The possible reason is that in method 2, the solvent may result in more acidic environment. As discussed previously [37], acidity environment could damage the nanoparticle surfaces that may quench the photoluminescence and afterglow properties of AG NPs.

\section{R11 Peptide Conjugation to Persistent Luminescence Nanoparticles:}

The cellular uptake of R11-AG conjugates were observed on two prostate cancer cell lines (PC-3 and LNCaP) in order to compare R11-NPs samples uptake as compared to NPs alone. It has been described that oligoarginine peptide (i.e., R11) appears to have high affinity to prostate cancer cells compared with other peptides [13, 23-25]. In addition R11 was developed as an imaging probe to detect prostate cancer [13, 23-25]. The uptake of R11 might be mediated through macropinocytosis. It was also concluded that the laminin receptor is one of the initial binding sites responsible for R11 peptide uptake in prostate cells. This indicates that the R11 peptides show greater specificity toward prostate cancer cells compared to other Cell-Permeable Peptides [24]. Figure 13 shows the results of the fluorescence imaging for R11-NP conjugates and NPs alone. As depicted in Figure 13, the R11-NPs conjugates show higher uptake for both PC-3 cells and LNCaP cells as compared to NPs alone. Moreover, by comparing the results shown in Figure 13, LNCaP cells show higher uptake as compared to PC-3 cells. These results are in agreement with a study by Wadajkar et al [23], where higher uptake of $\mathrm{R} 11-\mathrm{Fe} 2 \mathrm{O} 3$ nanopaticle conjugates than Fe2O3 nanoparticles alone by PC3 and LNCaP cells was observed. In addition, higher nanoparticle uptake by LNCaP cells as compared with those of PC3 cells was reported [23]. All these results demonstrate that R11 is a good targeting molecule that can target afterglow particles to prostate cancer cells. 


\section{Conclusions:}

Afterglow nanoparticles have been widely investigated for medical imaging and photodynamic activation for cancer destruction. For these applications, it is very important to target afterglow nanoparticles to cancer cells. In this study $\mathrm{Sr}_{3} \mathrm{MgSi}_{2} \mathrm{O}_{8}: \mathrm{Eu}^{2+}, \mathrm{Dy}^{3+}$ afterglow NPs were used in order to conjugate with variety of biomolecules, to qualitatively investigate cancer cells targeting. Based on all the results for florescent imaging related to different biomolecules used in this project, cellular uptake and targeting of luminescent NPs could be enhanced, by conjugation to variety of biomolecules which are specific for breast and prostate cancer and it was also shown that the cellular uptake is receptor dependent. For prostate cancer targeting, R11 peptide is the best candidate because of its higher specificity as compared to folic acid and RGD peptide. For breast cancer targeting, RGD peptide is highly recommended since it is more specific than folic acid. A cyclic RGD penta-peptide analog such as c (RGDfK), which was used in this study, is a promising candidate due to its high receptor binding affinity and specificity for breast cancer cells. The results demonstrated that afterglow nanoparticles can be effectively targeted to tumor cells. In vivo studies could be further considered in order to use these designed nanoparticulate systems in several biomedical applications.

\section{Acknowledgment}

We would like to acknowledge the support from the U.S. Army Medical Research Acquisition Activity (USAMRAA) under Contracts of W81XWH-10-1-0279 and W81XWH-101-0234 and the NSF and DHS joint ARI program (2008-DN-077-ARI016-05, CBET-1039068). We thank Professor Kytai Nguyen for permitting us to use some of the instruments in her lab and for providing us EDTA, Professor Jer-Tsong Hsieh in UT Southwestern Medical Center and Professor Richard Timmons at UT Arlington, Department of Chemistry and Biochemistry, for providing us with R11 peptide and plasma coated NPs, respectively.

\section{References}

1. Chen W. Nanoparticle self-lighting photodynamic therapy for cancer treatment. J. Biomed. Nanotechnol. 2008; 4: 369-376.

doi: 10.1166/jbn.2008.001

2. Homayoni H, Rashidi LH, Chen W. Combination of photodynamic therapy and nanotechnology: Non-invasive weapon against cancer. Rev. Nanosci. Nanotechnol. 2014; 3:107-132. 
doi: 10.1166/rnn.2014.1050.

3. Van den Eeckhout k, Smet PF, Poelman D. Persistent luminescence in $\mathrm{Eu}^{2+}$-doped compounds: A review. Materials. 2010; 3:2536- 2566.

doi: $10.3390 / \mathrm{ma3} 3042536$.

4. Yen WM, Yamamoto H. CRC Press/Taylor and Francis, $2^{\text {nd }}$ ed. Boca Raton, FL, USA: Phosphor Handbook; 2007.

5. Wang D, Yin Q, Li Y, Wang M. Concentration quenching of $\mathrm{Eu}^{2+}$ in $\mathrm{SrO} \cdot \mathrm{Al}_{2} \mathrm{O}_{3}: \mathrm{Eu}^{2+}$ phosphor. J. Lumin. 2002; 97: 1-6. doi: 0.1016/S0022-2313(01)00413-6.

6. Matsuzawa T, Aoki Y, Takeuchi N. A new long phosphorescen phosphor with high brightness, $\mathrm{SrAl}_{2} \mathrm{O}_{4}: \mathrm{Eu}^{2+}, \mathrm{Dy}^{3+}$. J. Electrochem, Soc.1996; 143: 2670-2673. doi: 10.1149/1.1837067.

7. Takasaki H, Tanabe S, Hanada T. Long-lasting afterglow characteristics of Eu, Dy codoped $\mathrm{SrO}-\mathrm{Al}_{2} \mathrm{O}_{3}$ phosphor. J. Ceram. Soc. Jpn. 1996; 104: 322-326

8. Lin Y, Tang Z, Zhang Z, Wang X, Zhang J. Preparation of a new long afterglow blue-emitting $\mathrm{Sr}_{2} \mathrm{MgSi}_{2} \mathrm{O}_{7}$-based photoluminescent phosphor. J. Mater. Sci. Lett. 2001; 20: 1505-1506. doi: 10.1023/A:1017930630889

9. Maia AS, Stefani R, Kodaira CA, Felinto MC, Teotonio EE, Brito HF. Luminescent nanoparticles of $\mathrm{MgAl}_{2} \mathrm{O}_{4}: \mathrm{Eu}$, Dy prepared by citrate sol-gel method. Opt. Mater. 2008; 31: 440-444. doi: 10.1016/j.optmat.2008.06.017

10. Chen W, Jun Z. Using nanoparticles to enable simultaneous radiation and photodynamic therapies for cancer treatment. J. Nanosci. Nanotechnol. . 2006; 6: 1159-1166. doi: 10.1166/jnn.2006.327.

11. Ma L, Wei C. ZnS: Cu, Co water-soluble afterglow nanoparticles: synthesis, luminescence and potential applications. Nanotechnol. 2010; 21: 385604. doi:10.1088/0957-4484/21/38/385604.

12. Chatterjee DK, Fong LS, Zhang Y. Nanoparticles in photodynamic therapy: an emerging paradigm. Adv. Drug Deliv. Rev. 2008; 60: 1627-1637. doi:10.1016/j.addr.2008.08.003. 
13. Rashidi LH, Homayoni H, Chen W. Nanoparticle applications and targeting strategies in cancer diagnosis and treatment. Rev. Nanosci. Nanotechnol. 2014; 3: 31-51.

doi: 10.1166/rnn.2014.1044.

14. Sudimack J, Lee. RJ. Targeted drug delivery via the folate receptor. Adv. Drug Deliv. Rev. 2000; 41: 147-162.

doi:10.1016/S0169-409X(99)00062-9

15. Gu FX, Karnik R, Wang AZ, Alexis F, Levy-Nissenbaum E, Hong S, Langer, RS Farokhzad OC. Targeted nanoparticles for cancer therapy. Nano today, 2007; 2: 14-21. doi:10.1016/S1748-0132(07)70083-X.

16. Dutta RK, Sharma PK, Pandey AC. Design and surface modification of potential luminomagnetic nanocarriers for biomedical applications. J. Nanopart. Res. 2010; 12: 12111219.

doi: 10.1007/s11051-009-9801-0.

17. Kamaly N, Xiao Z, Valencia PM, Radovic-Moreno AF, Farokhzad OC. Targeted polymeric therapeutic nanoparticles: design, development and clinical translation. Chem. Soc. Rev. 2012; 41: 2971-3010.

doi: 10.1039/C2CS15344K.

18. Yang W, Meng L, Wang H, Chen R, Wang R, Ma X, Xu G, Zhou J, Wang S, Lu Y, Ma D. Inhibition of proliferative and invasive capacities of breast cancer cells by arginine-glycineaspartic acid peptide in vitro. Oncol. Rep. 2006; 15: 113-117.

doi:10.3892/or.15.1.113.

19. Ye Y, Chen X. Integrin targeting for tumor optical imaging. Theranostics. 2011; 1: 102. doi: 10.7150/thno/v01p0102.

20. Wang Z, Chui WK, Ho PC. Design of a multifunctional PLGA nanoparticulate drug delivery system: evaluation of its physicochemical properties and anticancer activity to malignant cancer cells. Pharm. Res 2009; 26: 1162-1171.

doi: 10.1007/s11095-009-9837-y.

21. Valencia PM, Hanewich-Hollatz MH, Gao W, Karim F, Langer R, Karnik R, Farokhzad OC. Effects of ligands with different water solubilities on self-assembly and properties of targeted nanoparticles. Biomater. 2011; 32: 6226-6233.

doi: 10.1016/j.biomaterials.2011.04.078 
22. Wang F, Li Y, Shen Y, Wang A, Wang S, Xie T. The Functions and Applications of RGD in Tumor Therapy and Tissue Engineering. Int. J. Mol. Sci. 2013; 14: 13447-13462. doi: 10.3390/ijms 140713447.

23. Wadajkar AS, Menon JU, Tsai YS, Gore C, Dobin T, Gandee L, Kangasniemi K, Takahashi M, Manandhar B, Ahn JM, Hsieh JT, Nguyen KT. Prostate cancer-specific thermoresponsive polymer-coated iron oxide nanoparticles. Biomater. 2013; 34: 3618-3625. doi:10.1016/j.biomaterials.2013.01.062.

24. Zhou J, Liu W, Pong RC, Hao G, Sun X, Hsieh JT. Analysis of oligo-arginine cellpermeable peptides uptake by prostate cells. Amino acids. 2012; 42: 1253-1260. doi: 10.1007/s00726-010-0817-7.

25. Zhou J, Fan J, Hsieh JT. Inhibition of mitogen-elicited signal transduction and growth in prostate cancer with a small peptide derived from the functional domain of DOC-2/DAB2 delivered by a unique vehicle. Cancer Res. 2006; 66: 8954-8958. doi: 10.1158/0008-5472.CAN-06-1726.

26. Homayoni, H. Protoporphyrin IX (PpIX) -Conjugated Self-Lighting Nanoparticles for Photodynamic Therapy: Synthesis and Characterization. University of Texas at Arlington, 2013.

27. Durdureanu-Angheluta A, Dascalu A, Fifere A, Coroaba, A, Pricop L, Chiriac H, Tura V, Pinteala M, Simionescu BC. Progress in the synthesis and characterization of magnetite nanoparticles with amino groups on the surface. J. Magn. Magn. Mater. 2012; 324: 16791689.

doi: 10.1016/j.jmmm.2011.11.062.

28. Vohra V. Multilevel organization of hybrid materials based on zeolite L crystals for light emitting devices applications. Diss. Università degli Studi di Milano-Bicocca, 2009.

29. Kehr NS, Riehemann K, El-Gindi J, Schäfer A, Fuchs H, Galla HJ, De Cola L. Cell Adhesion and Cellular Patterning on a Self-Assembled Monolayer of Zeolite L Crystals. Adv. Funct. Mater. 2010; 20: 2248-2254.

doi: 10.1002/adfm.201000205.

30. Yuan P, Southon PD, Liu Z, Green ME, Hook JM, Antill SJ, Kepert CJ. Functionalization of halloysite clay nanotubes by grafting with $\gamma$-aminopropyltriethoxysilane. J. Phys. Chem. C. 2008; 112: 15742-15751. 
doi: 10.1021/jp805657t.

31. Gao R, Zhang J, He X, Chen L, Zhang Y. Selective extraction of sulfonamides from food by use of silica-coated molecularly imprinted polymer nanospheres. Anal. Bioanal. Chem. 2010; 398: 451-461.

doi: 10.1007/s00216-010-3909-z

32. Xiong LQ, Chen ZG, Yu MX, Li FY, Liu C, Huang CH. Synthesis, characterization, and in vivo targeted imaging of amine-functionalized rare-earth up-converting nanophosphors. Biomater. 2009; 30: 5592-5600.

doi: 10.1016/j.biomaterials.2009.06.015.

33. Sunoqrot S, Bae JW, Pearson RM, Shyu K, Liu Y, Kim DH, Hong S. Temporal control over cellular targeting through hybridization of folate-targeted dendrimers and PEG-PLA nanoparticles. Biomacromolecules. 2012; 13: 1223-1230.

doi: 10.1021/bm300316n.

34. Narayanan S, Binulal NS, Mony U, Manzoor K, Nair S, Menon D. Folate targeted polymeric'green'nanotherapy for cancer. Nanotechnol. 2010; 21: 285107. doi: 10.1088/0957-4484/21/28/285107.

35. SHAN J. Use of upconversion fluorescent nanoparticles for simultaneous imaging, detection and delivery of sirna. National University of Singapore, 2009.

36. Suriamoorthy P, Zhang X, Hao G, Joly AG, Singh S, Hossu M, Sun X, Chen W. Folic acidCdTe quantum dot conjugates and their applications for cancer cell targeting. Cancer Nanotechnol. 2010; 1: 19-28.

doi: 10.1007\%2Fs12645-010-0003-3.

37. Hossein Rashidi L. Investigation of nanoparticle delivery to cancer cells by conjugation to various targeting moieties. University of Texas at Arlington, 2013.

38. Wang Z, Chui WK, and Ho PC. Nanoparticulate delivery system targeted to tumor neovasculature for combined anticancer and antiangiogenesis therapy. Pharm. Res. 2011; 28: 585-596.

doi: 10.1007/s11095-010-0308-2.

39. Chen R, Curran SJ, Curran JM, Hunt JA. The use of poly (l-lactide) and RGD modified microspheres as cell carriers in a flow intermittency bioreactor for tissue engineering cartilage. Biomater. 2006; 27: 4453-4460. 
doi: 10.1016/j.biomaterials.2006.04.011.

40. Wang Z, and Ho PC. Self-Assembled Core-Shell Vascular-Targeted Nanocapsules for Temporal Antivasculature and Anticancer Activities. Small. 2010; 6: 2576-2583. doi: $10.1002 /$ smll.201001122.

41. Jain R, Agarwal A, Kierski PR, Schurr MJ, Murphy CJ, McAnulty JF, Abbott NL. The use of native chemical functional groups presented by wound beds for the covalent attachment of polymeric microcarriers of bioactive factors. Biomater. 2012; 34: 340-352.

doi: 10.1016/j.biomaterials.2012.09.055.

42. Hao G, Zhou J, Guo Y, Long MA, Anthony T, Stanfield J, Hsieh JT, Sun X. A cell permeable peptide analog as a potential-specific PET imaging probe for prostate cancer detection. Amino acids. 2011; 41: 1093-1101.

doi: 10.1007/s00726-010-0515-5.

43. Majoros IJ, Williams CR, Becker A, Baker JR. Methotrexate delivery via folate targeted dendrimer-based nanotherapeutic platform. Wiley Interdisciplinary Reviews: Nanomedicine and Nanobiotechnology. 2009; 1: 502-510.

doi: 10.1002/wnan.37.

44. Das M, Sahoo SK. Folate decorated dual drug loaded nanoparticle: role of curcumin in enhancing therapeutic potential of nutlin-3a by reversing multidrug resistance. PIOS ONE. 2012; 7: e32920.

doi: 10.1371/journal.pone.0032920.

45. Geszke M, Murias M, Balan L, Medjahdi G, Korczynski J, Moritz M, Lulek J, Schneider R. Folic acid-conjugated core/shell $\mathrm{ZnS}: \mathrm{Mn} / \mathrm{ZnS}$ quantum dots as targeted probes for two photon fluorescence imaging of cancer cells. Acta Biomater. 2011; 7: 1327-1338. doi: 10.1016/j.actbio.2010.10.012.

46. Lakshmanan SB. Gold/Copper Sulphide and Gold Nanoparticles for Application in Cancer Therapy. University of Texas at Arlington, 2012.

47. Yang C, Ma L, Zou X, Xiang G, Chen W. Surface plasmon-enhanced Ag/CuS nanocomposites for cancer treatment. Cancer Nanotechnol. 2013; 4: 81-89. doi: 10.1007/s12645-013-0039-2.

48. Tyagi A, Penzkofer A. Fluorescence spectroscopic behaviour of folic acid. J. Chem. Phys. 2010; 367: 83-92. 
doi: 10.1016/j.chemphys.2009.10.026.

49. Hirakawa K, Suzuki H, Oikawa S, Kawanishi S. Sequence-specific DNA damage induced by ultraviolet A-irradiated folic acid via its photolysis product. Arch. Biochem. Biophys. 2003; 410: 261-268.

doi: 10.1016/S0003-9861(02)00722-1.

50. Hattori Y, and Maitani Y. Folate-linked lipid-based nanoparticle for targeted gene delivery. Curr. Drug Delivery. 2005; 2: 243-252.

doi: 10.1002/9783527610419.ntls0009.

51. Zhou J, Yao L, Li C, Li F. A versatile fabrication of upconversion nanophosphors with functional-surface tunable ligands. J. Mater. Chem. 2010; 20: 8078-8085. doi: 10.1039/C0JM01041C.

52. Pi J, Jin H, Liu R, Song B, Wu Q, Liu L, Jiang J, Yang F, Cai H, Cai J. Pathway of cytotoxicity induced by folic acid modified selenium nanoparticles in MCF-7 cells. Appl. Microbiol. Biotechnol. 2013; 97.3: 1051-1062.

doi: 10.1007/s00253-012-4359-7.

53. Pan J, Feng SS. Targeting and imaging cancer cells by folate-decorated, quantum dots (QDs)-loaded nanoparticles of biodegradable polymers. Biomater. 2009; 30: 1176-1183. doi: 10.1016/j.biomaterials.2008.10.039.

54. Retnakumari A, Setua S, Menon D, Ravindran P, Muhammed H, Pradeep T, Nair S, Koyakutty M. Molecular-receptor-specific, non-toxic, near-infrared-emitting Au clusterprotein nanoconjugates for targeted cancer imaging. Nanotechnol. 2010; 21: 055103. doi: 10.1088/0957-4484/21/5/055103.

55. Liu Y, Sun J, Cao W, Yang J, Lian H, Li X, Sun Y, Wang Y, Wang S, He Z. Dual targeting folate-conjugated hyaluronic acid polymeric micelles for paclitaxel delivery. Int. J. Pharm. 2011; 421: 160-169.

doi: 10.1016/j.jpharm.2011.09.006.

56. Cai W, Shin DW, Chen K, Gheysens O, Cao Q, Wang SX, Gambhir SS, Chen X Peptidelabeled near-infrared quantum dots for imaging tumor vasculature in living subjects. Nano Lett. 2006; 6: 669-676.

doi: $10.1021 / \mathrm{n} 1052405 \mathrm{t}$. 
Figure captions:

Figure 1: Schematic of APTES coating on the surface of AG NPs

Figure 2: Schematic of FA conjugation to AG NPs

Figure 3: Schematic of RGD peptide conjugation to AG NPs

Figure 4: Schematic of RGD peptide conjugation to plasma coated AG NPs

Figure 5: Schematic of R11 peptide conjugation to AG NPs

Figure 6: The excitation (PLE, left) and emission (PL, right) spectra Of NP only, NP-FA conjugation and FA only. . The monitored emission wavelengths for the measurement of the excitation spectra and the excitation wavelengths for the measurement of the emission spectra are displayed in the figure.

Figure 7: Fluorescence and afterglow properties of AG NPs conjugated to folic acid, under UV lamp: (A) MES method (B) DMSO method

Figure 8: Absorption spectra of FA alone- $23.4375 \mu \mathrm{g} / \mathrm{ml}$ (A), FA conjugated AG NPs- 125 $\mu \mathrm{g} / \mathrm{ml}$ (B) and AG NPs alone- $125 \mu \mathrm{g} / \mathrm{ml}$ (C).

Figure 9: Cell viability enhancement for conjugated FA NPs using MTT assay $(*$ : P $<0.05$, NC: Negative Control)

Figure 10: Fluorescent imaging and cellular uptake comparison for PC-3, MCF-7 and KB cell lines: Top row: Bright field, Second row: Nucleus staining with PI (Ex: 535 nm, Em: 625 nm), Third row: Conjugated FA-NPs fluorescence (Ex: $350 \mathrm{~nm}$, Em: $450 \mathrm{~nm}$ ), Bottom row: Merge of second and third row. PC-3 cells scale bar: $50 \mu \mathrm{m}, \mathrm{MCF}-7$ and KB cells scale bar: $20 \mu \mathrm{m}$.

Figure 11: Fluorescent imaging and cellular uptake comparison for MCF-7 and MDA-MB-231 cell lines (method 1): Top row: Bright field, Second row: Nucleus staining with PI (Ex: $535 \mathrm{~nm}$, Em: $625 \mathrm{~nm}$ ), Third row: Conjugated RGD-NPs fluorescence (Ex: $350 \mathrm{~nm}$, Em: 450), Bottom row: Merge of second and third row. Sacle bar: $20 \mu \mathrm{m}$.

Figure 12: Fluorescent imaging and cellular uptake comparison for MCF-7 and MDA-MB-231 cell lines (method 2): Top row: Bright field, Second row: Nucleus staining with PI (Ex: $535 \mathrm{~nm}$, Em: $625 \mathrm{~nm}$ ), Third row: Conjugated RGD-NPs

Figure 13: Comparison of fluorescent imaging and cellular uptake for PC-3 and LNCaP cell lines by using two different samples: First two top rows: Conjugated R11-NPs, Last two bottom rows: 
NPs alone, Nucleus staining with PI (Ex: $535 \mathrm{~nm}$, Em: $625 \mathrm{~nm}$ ), Conjugated R11-NPs and NPs fluorescence (Ex: $350 \mathrm{~nm}$, Em: 450). Scale bar: $20 \mu \mathrm{m}$. 


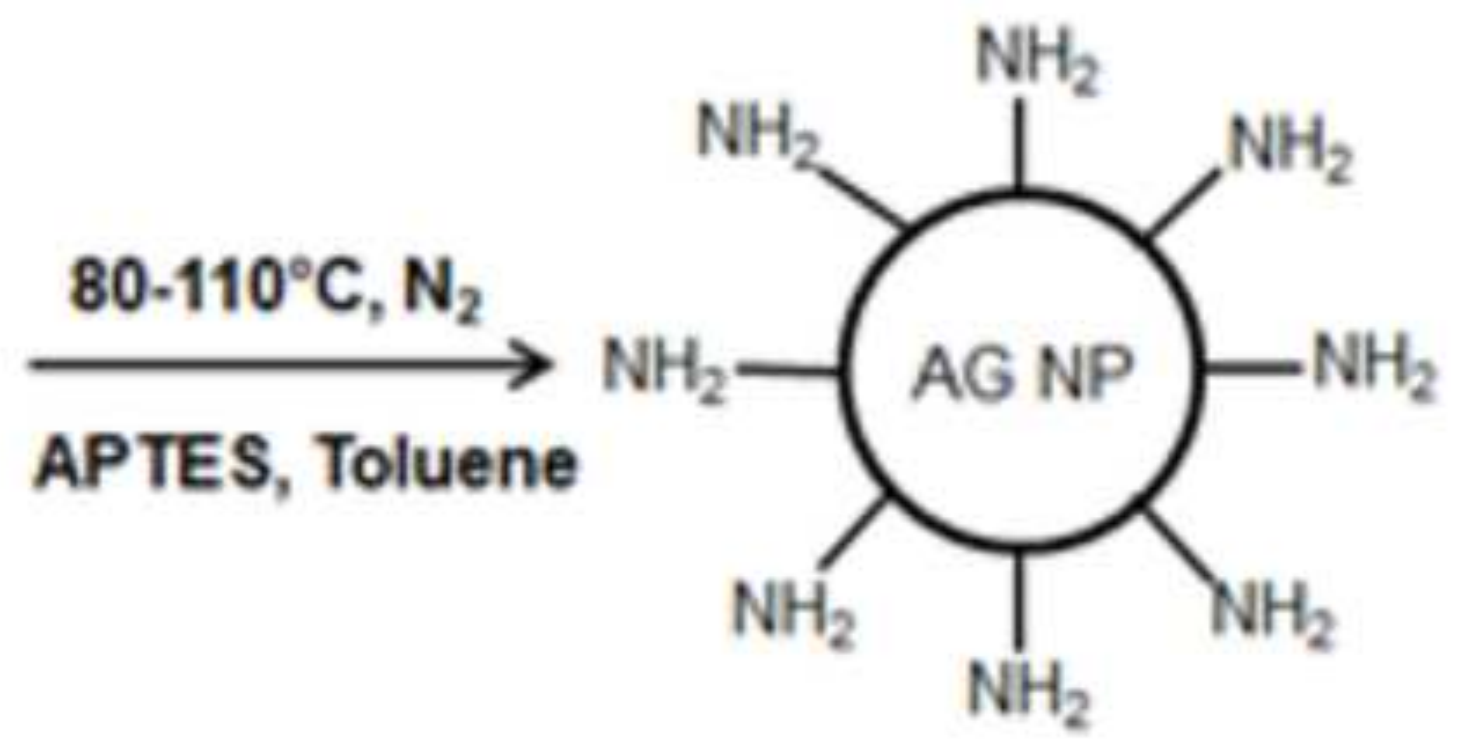

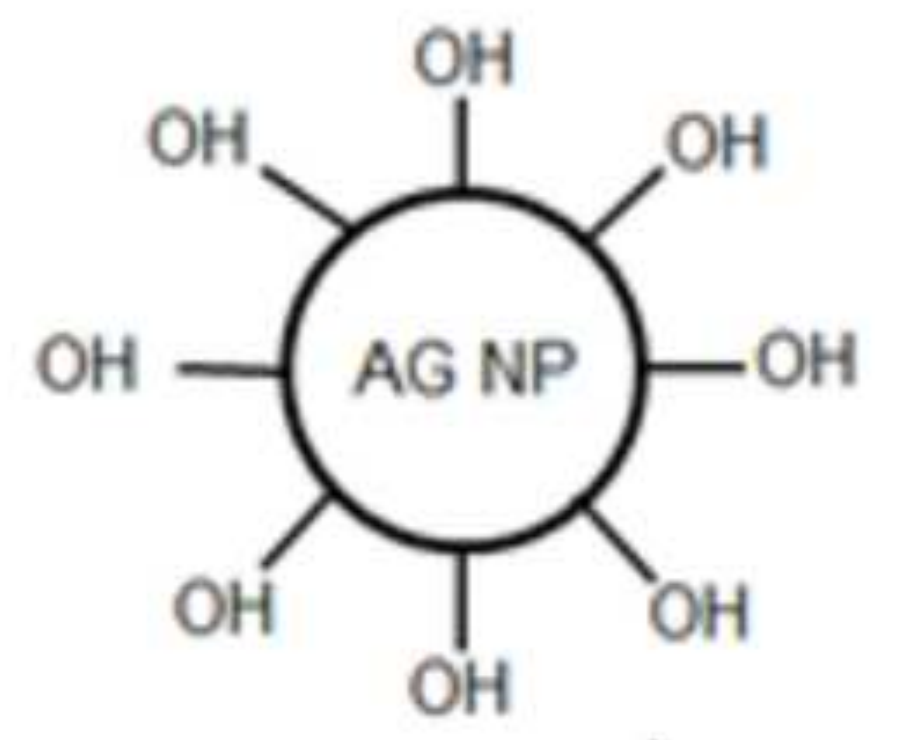
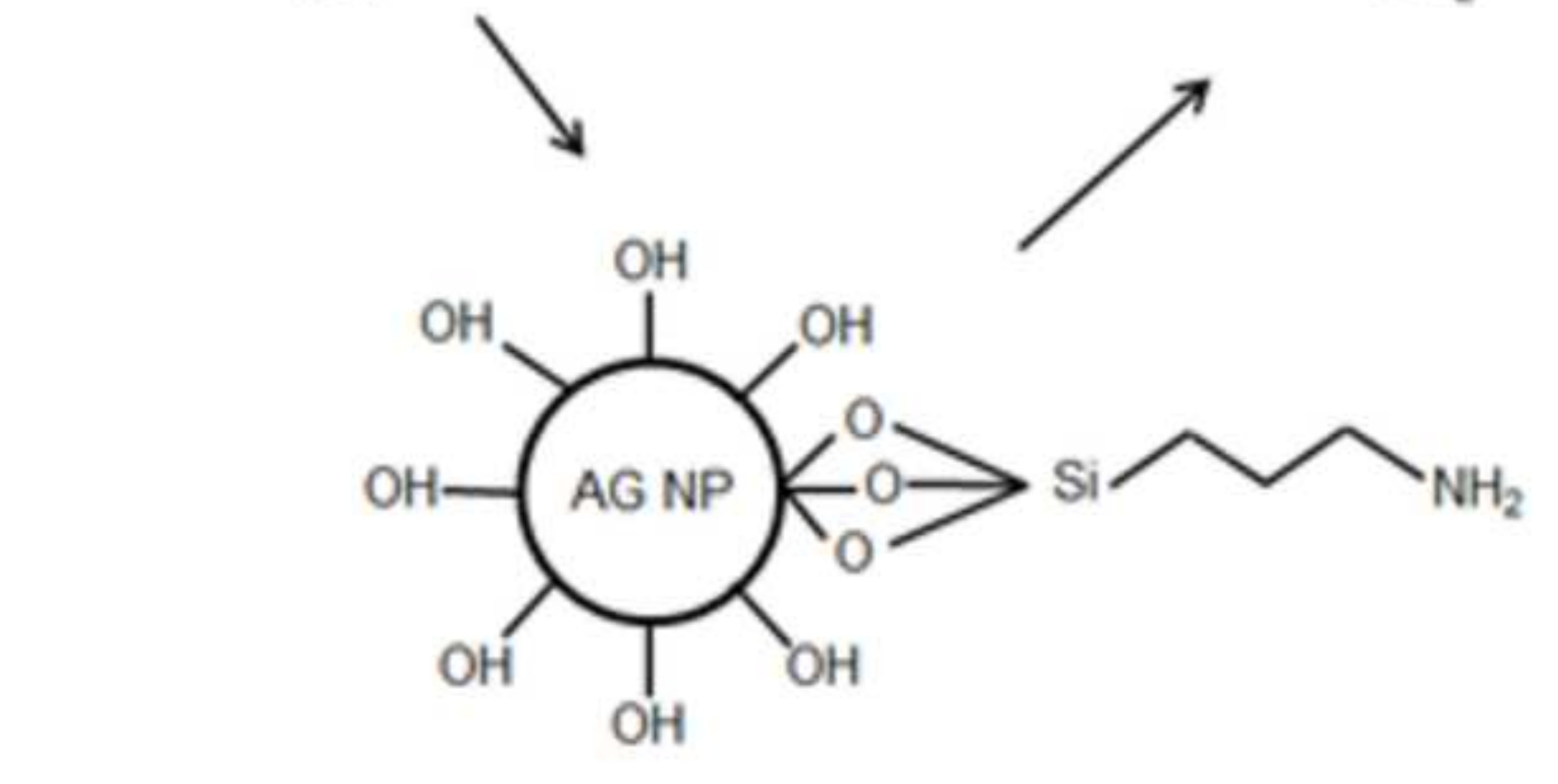

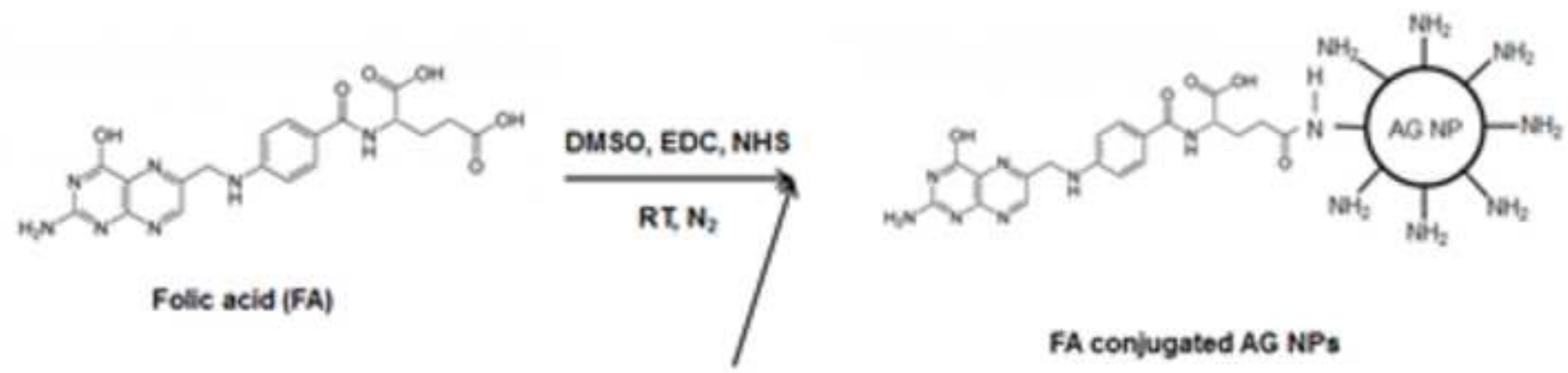

\section{FA conlugated AG NPs}

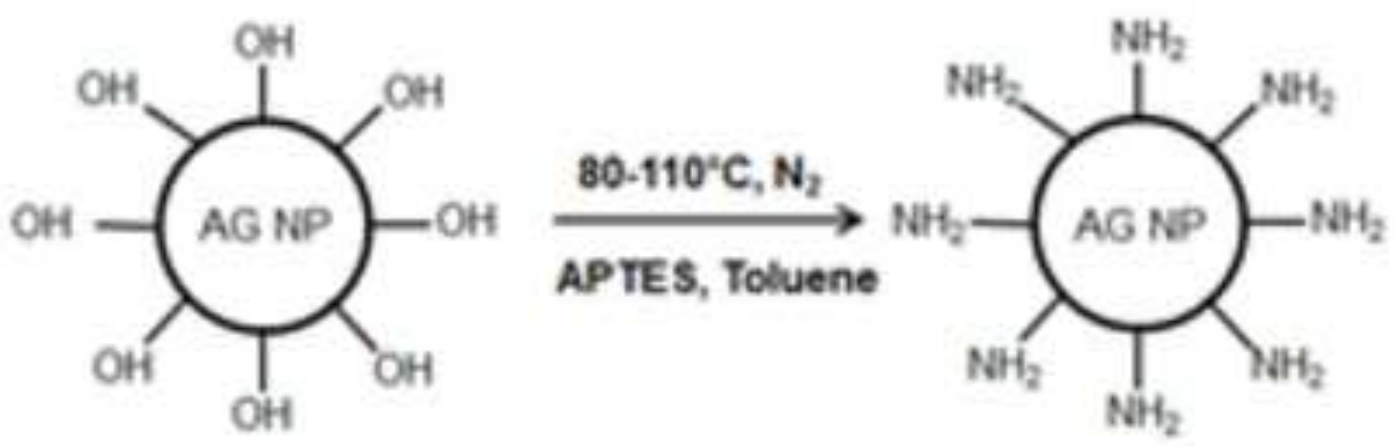




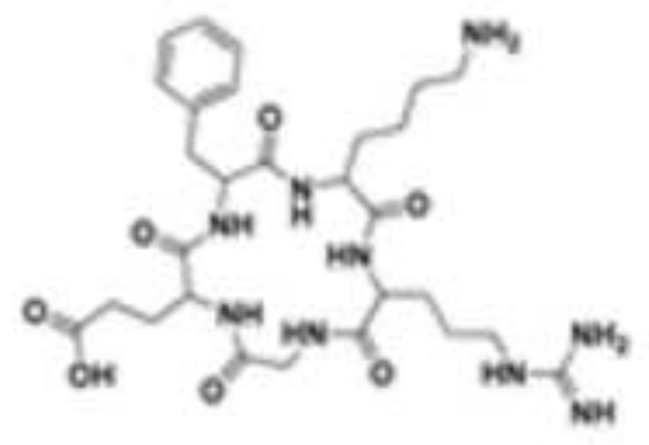

RGD peptide

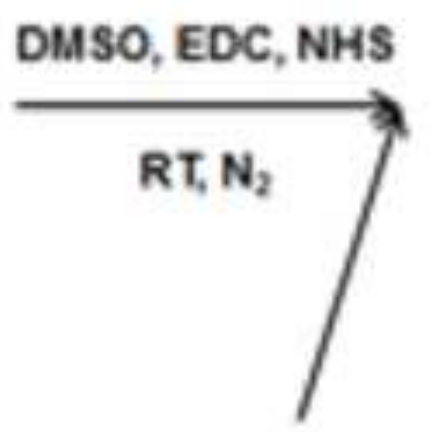

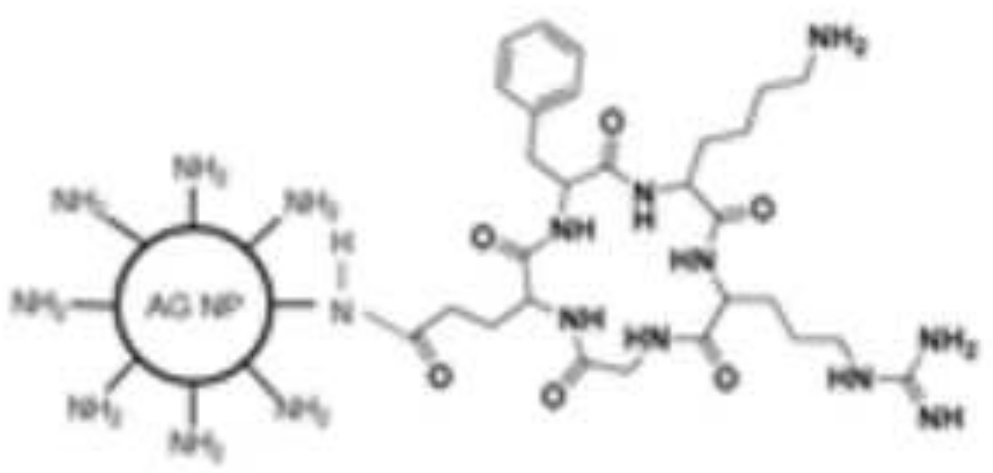

RGD pepEde conjugated AG NPs
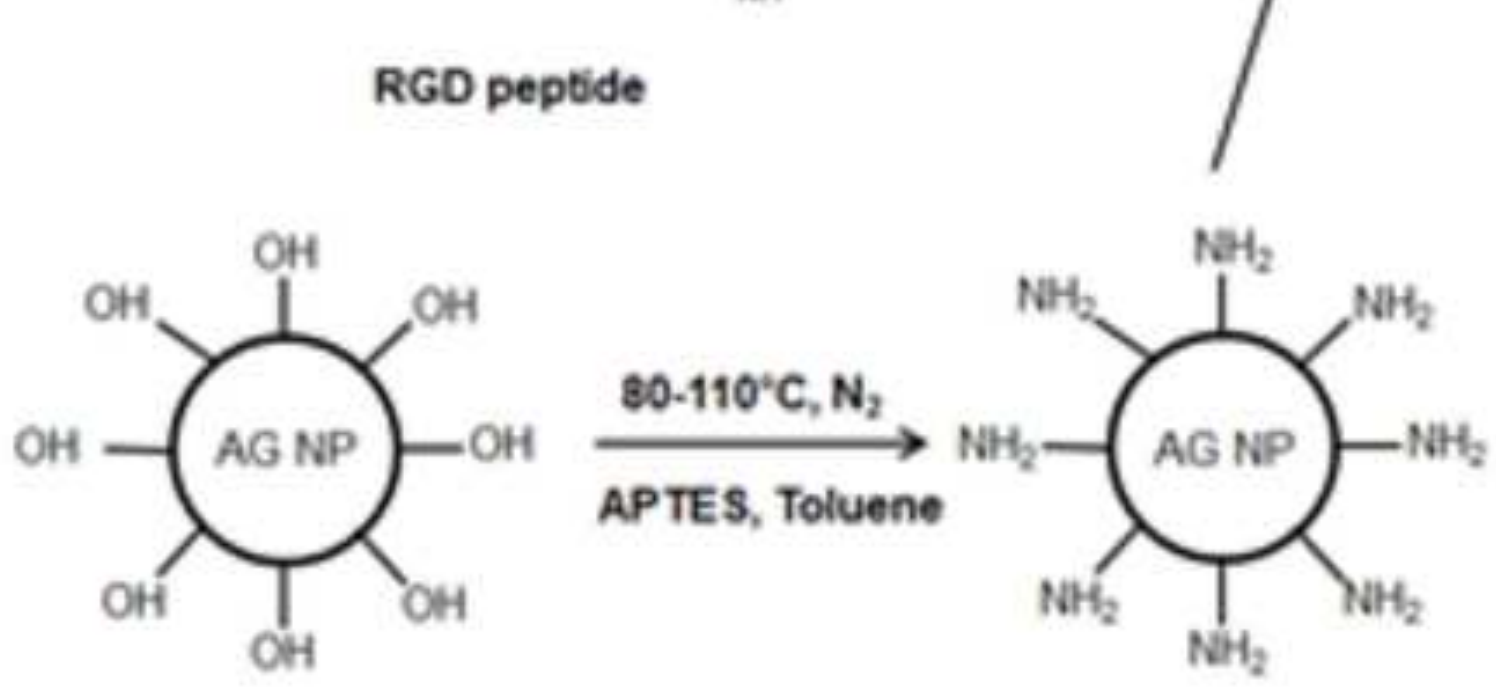

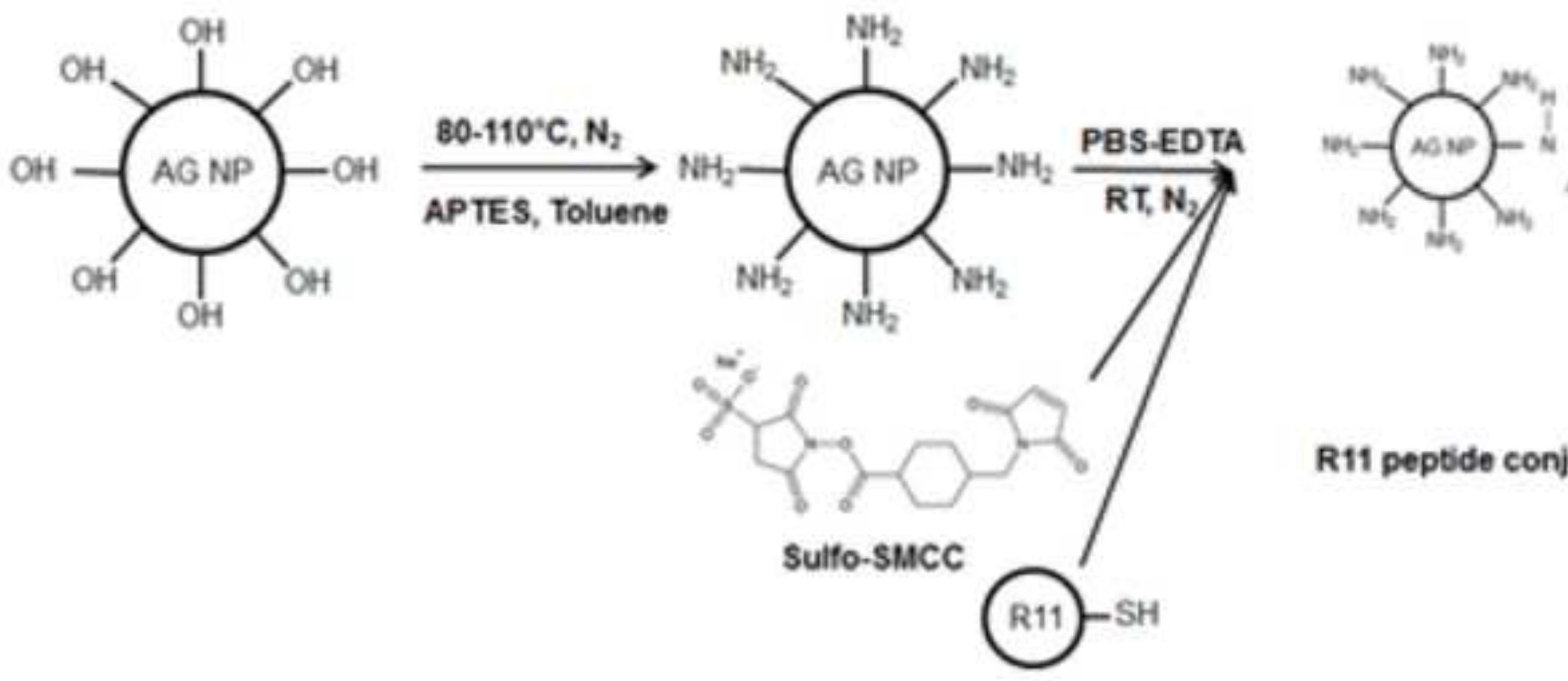

R11 peptide conjugated AG NPs 


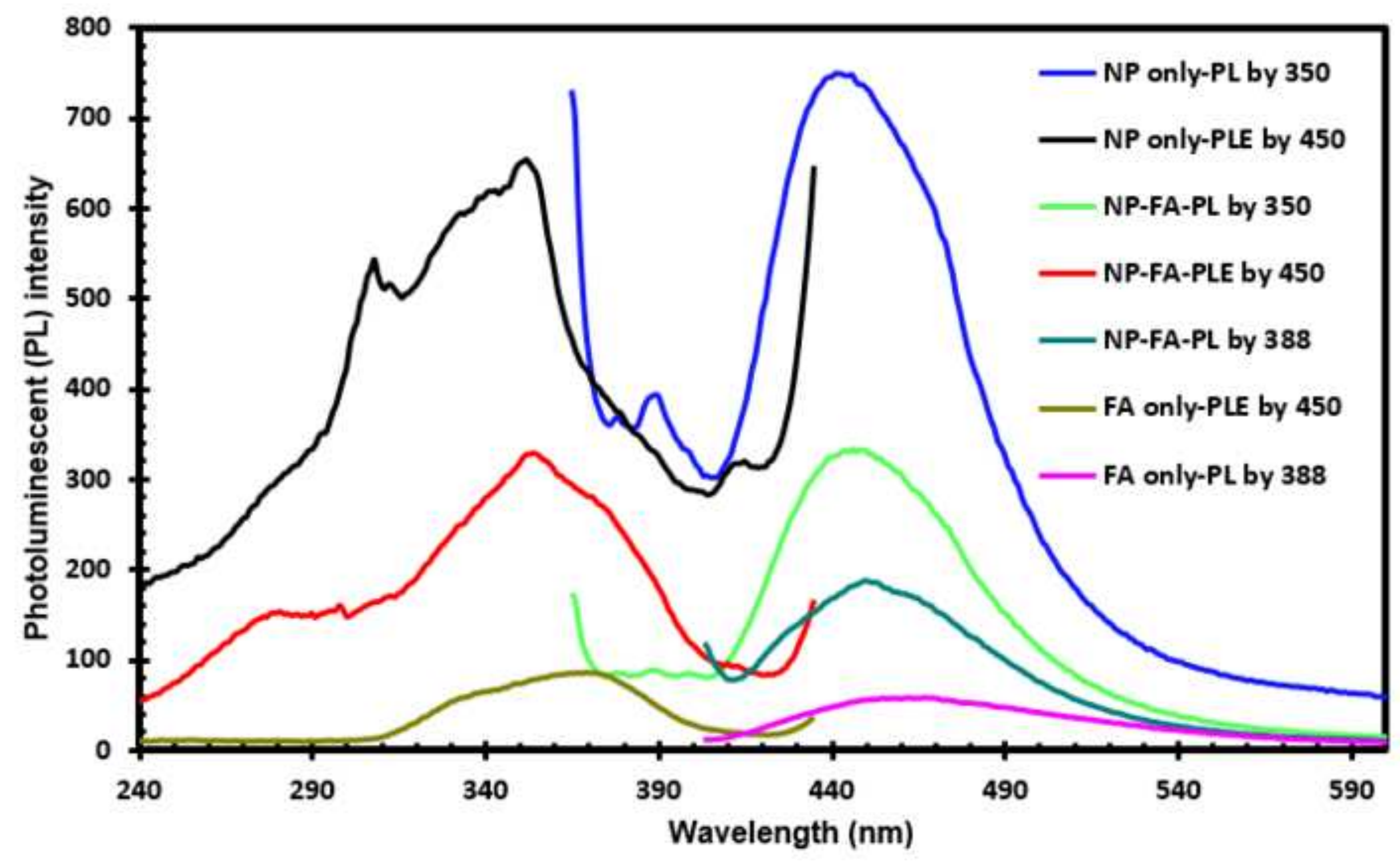




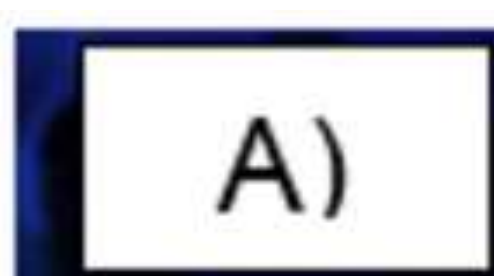

\section{B)}
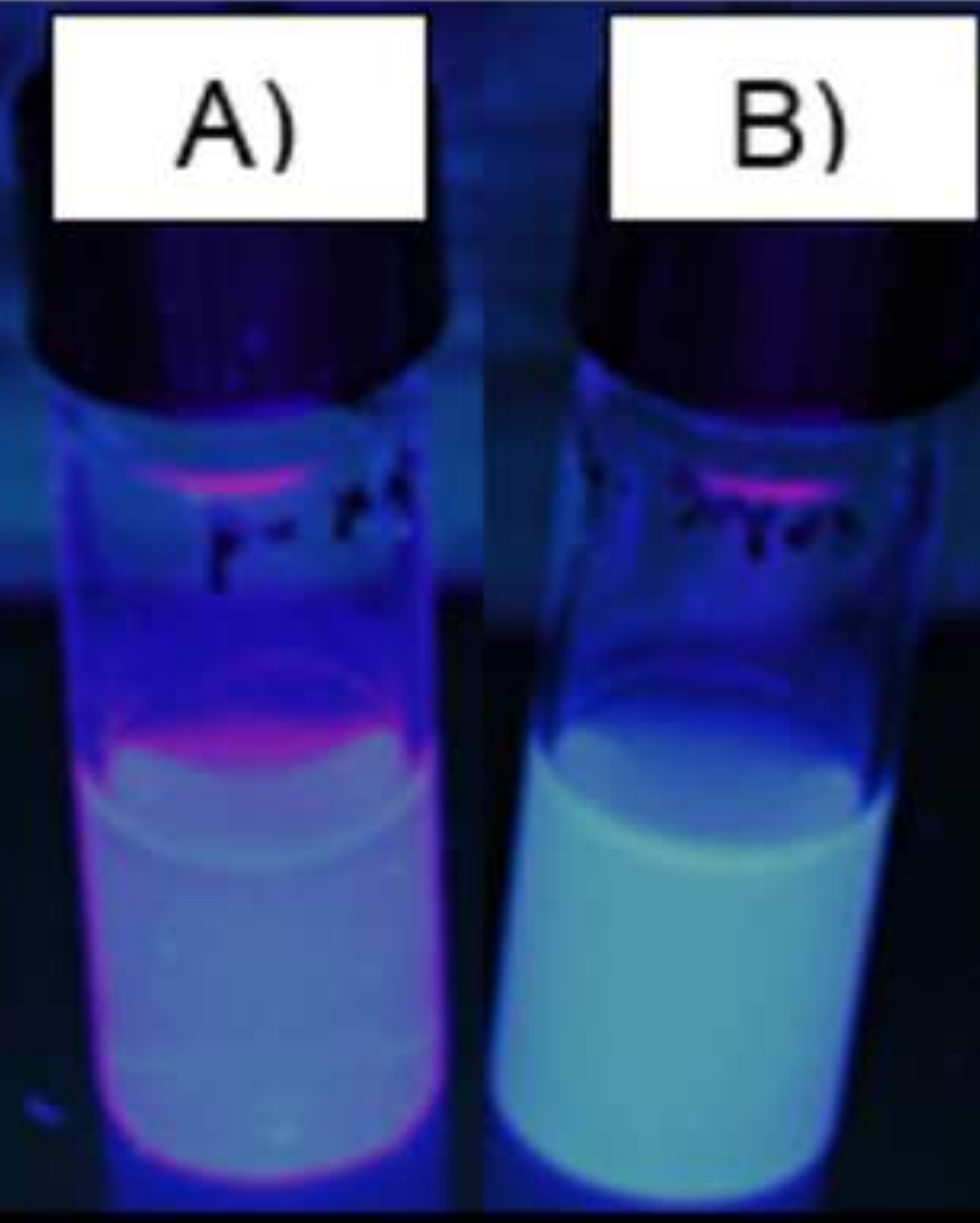

Figure 7

A)

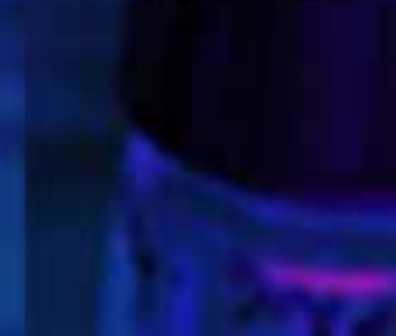




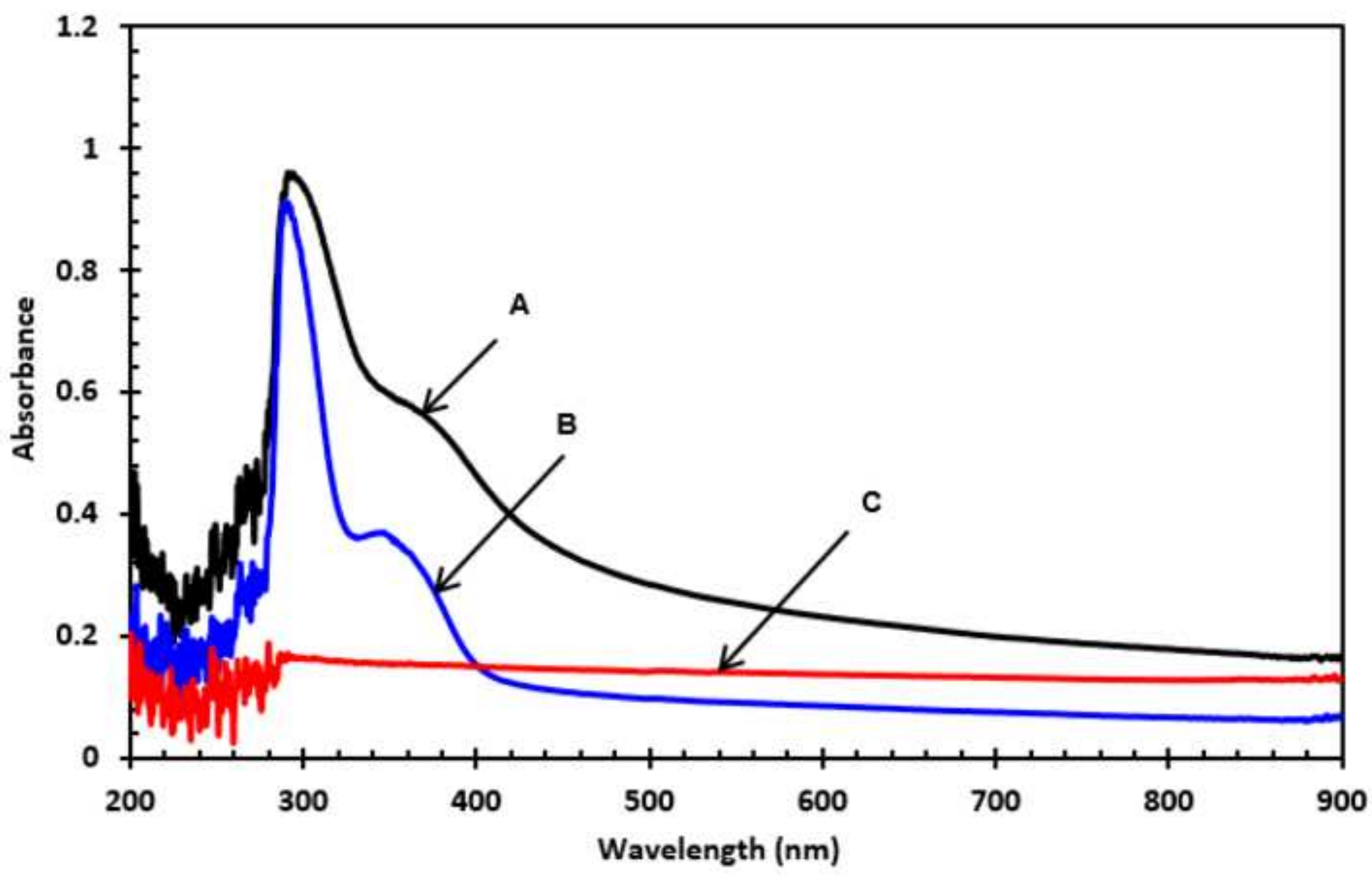




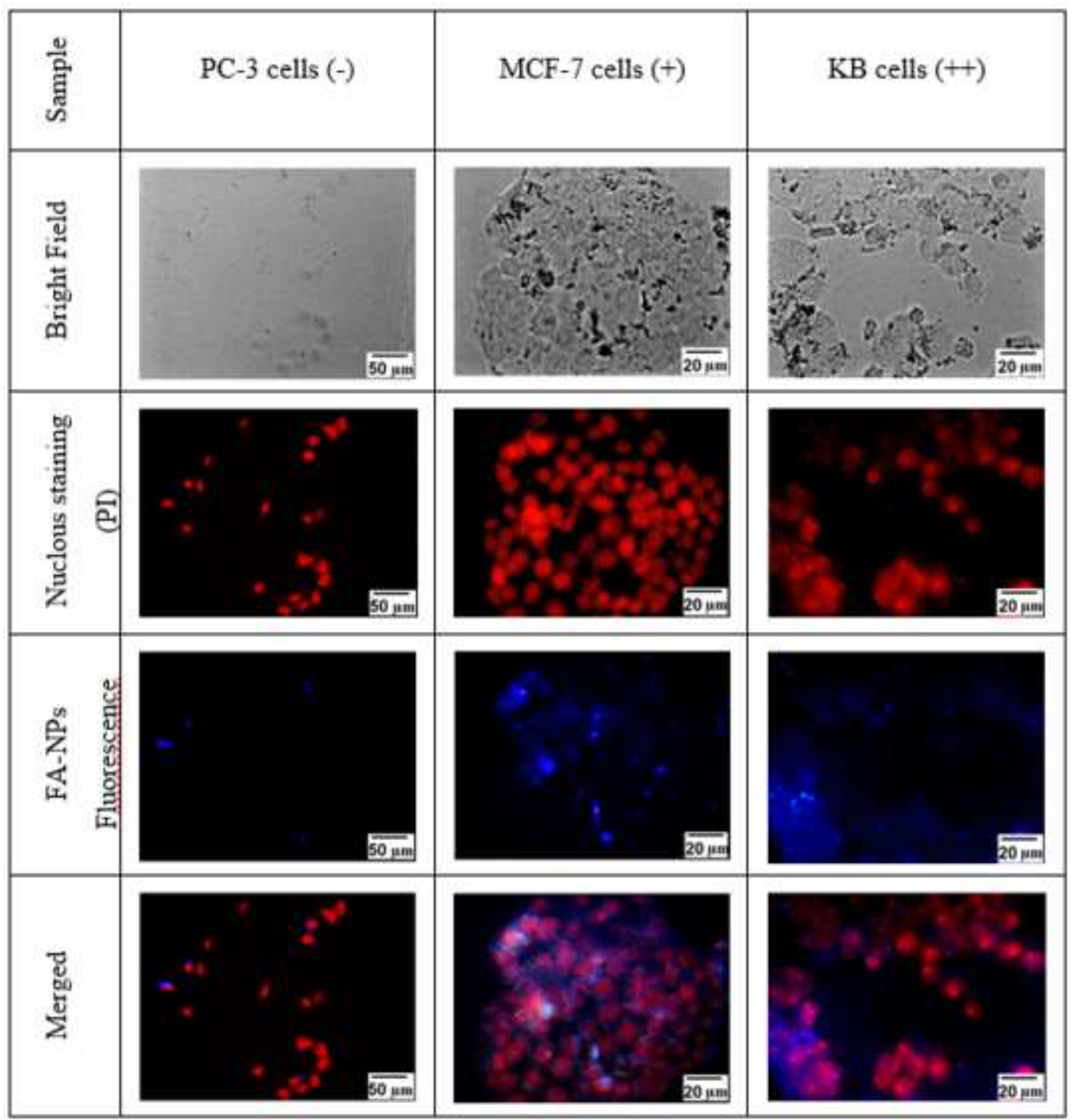




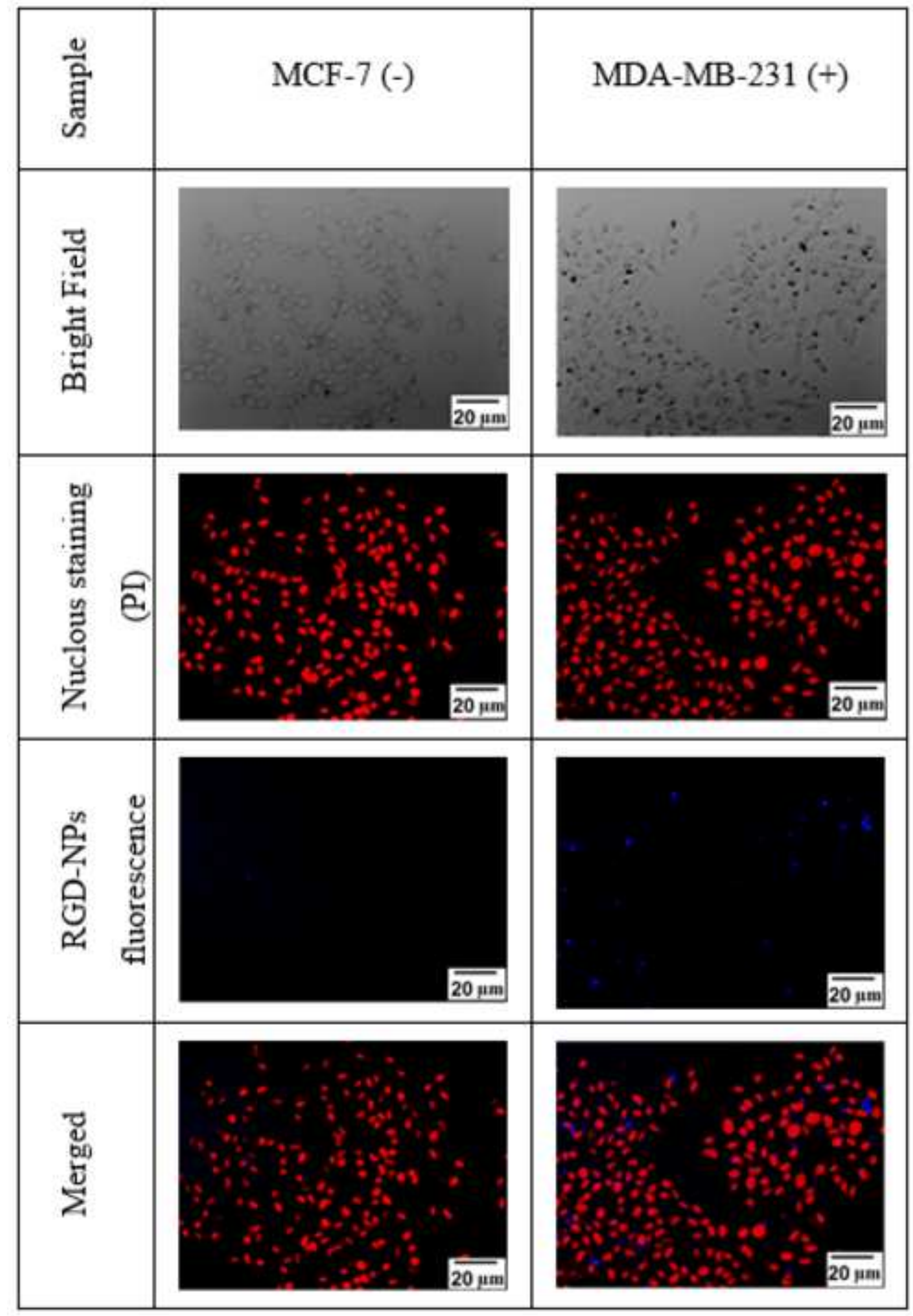

Figure 11

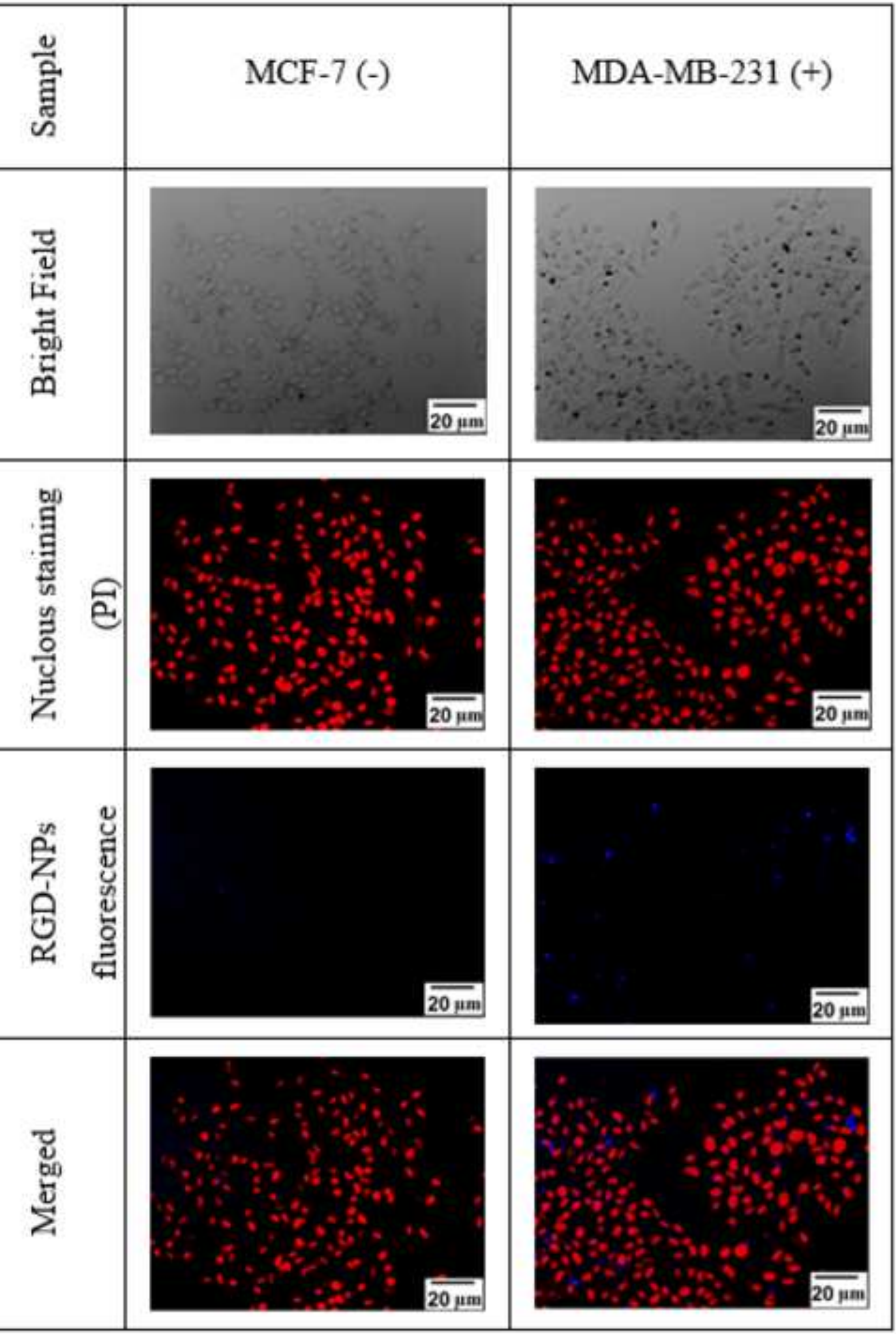

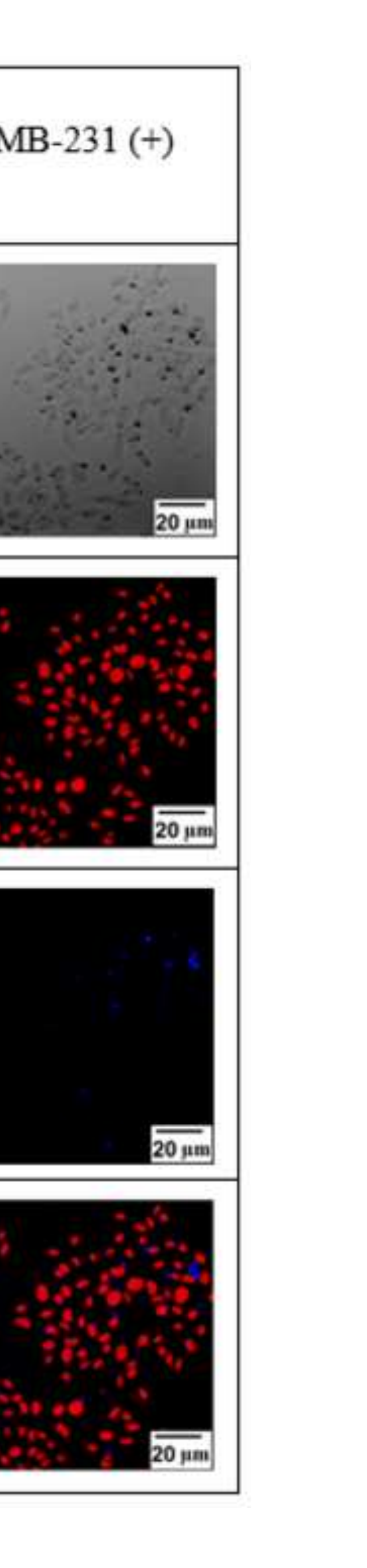




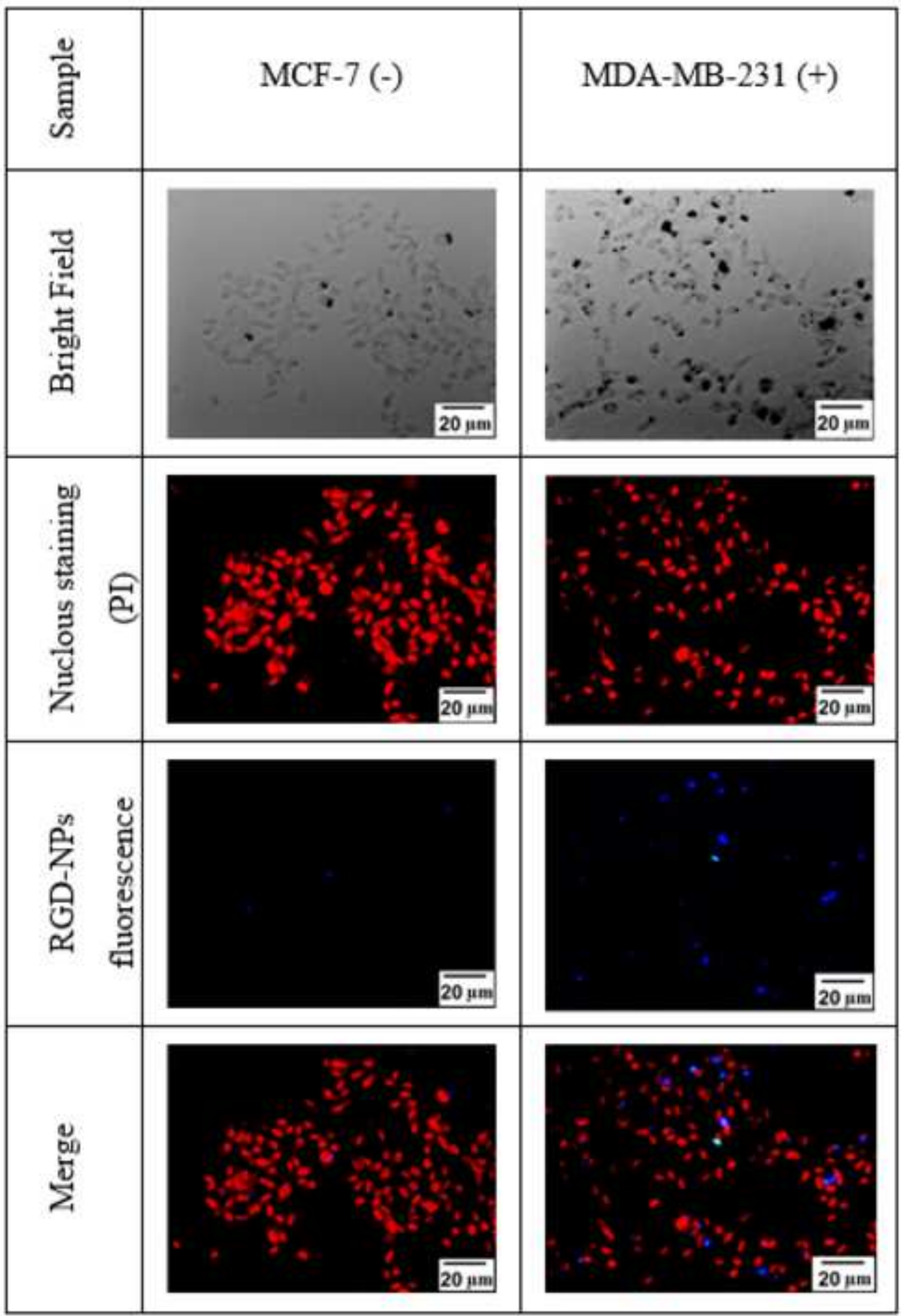




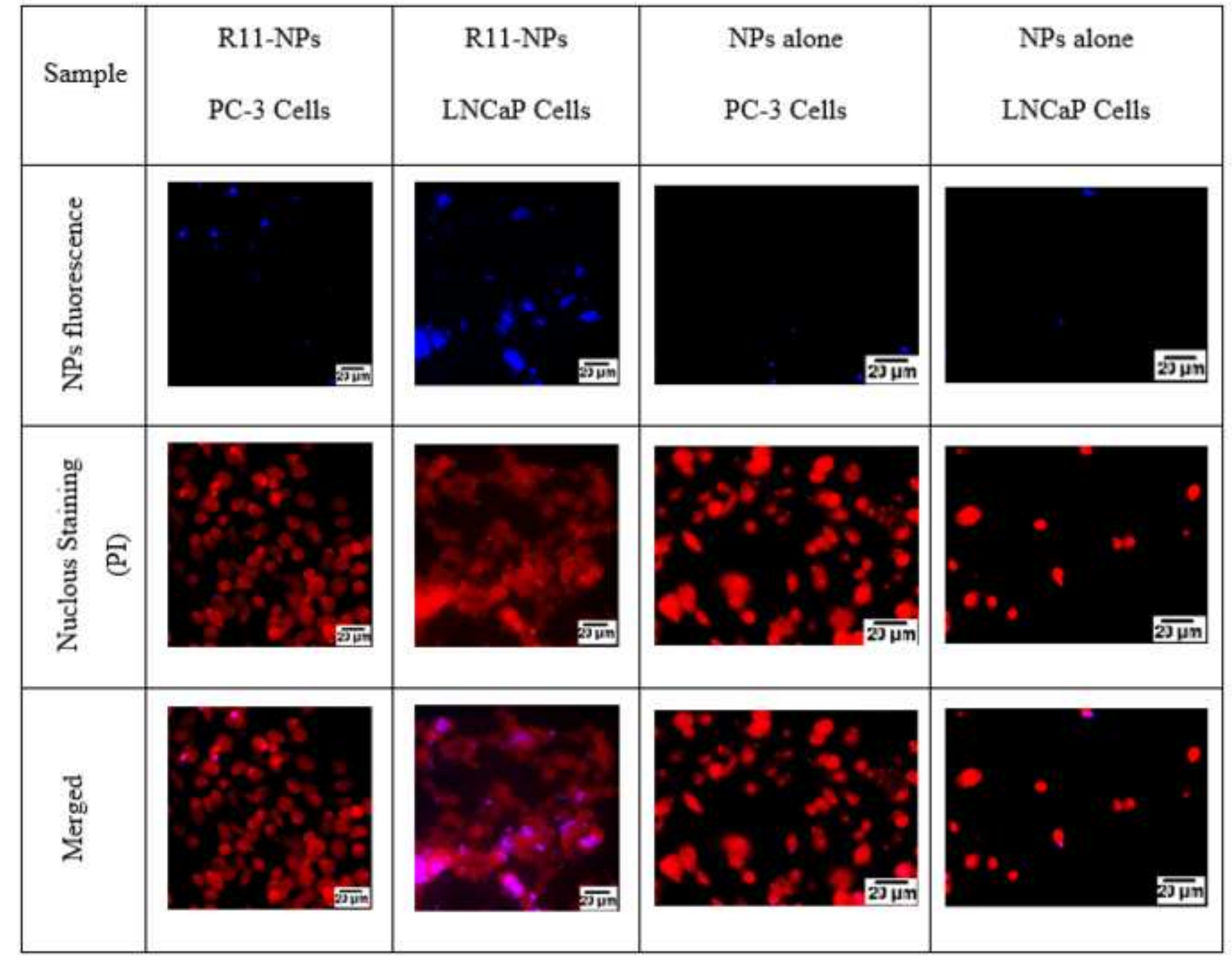

